\title{
In Situ Remediation of 137Cs Contaminated Wetlands Using Naturally Occurring Minerals
}

by

D. I. Kaplan

Westinghouse Savannah River Company

Savannah River Site

Aiken, South Carolina 29808

T. G. Hinton

SREL

A. C. Knox

SREL

S. M. Serkiz

DOE Contract No. DE-AC09-96SR18500

This paper was prepared in connection with work done under the above contract number with the U. S. Department of Energy. By acceptance of this paper, the publisher and/or recipient acknowledges the U. S. Government's right to retain a nonexclusive, royalty-free license in and to any copyright covering this paper, along with the right to reproduce and to authorize others to reproduce all or part of the copyrighted paper. 


\section{DISCLAIMER}

This report was prepared as an account of work sponsored by an agency of the United States Government. Neither the United States Government nor any agency thereof, nor any of their employees, makes any warranty, express or implied, or assumes any legal liability or responsibility for the accuracy, completeness, or usefulness of any information, apparatus, product, or process disclosed, or represents that its use would not infringe privately owned rights. Reference herein to any specific commercial product, process, or service by trade name, trademark, manufacturer, or otherwise does not necessarily constitute or imply its endorsement, recommendation, or favoring by the United States Government or any agency thereof. The views and opinions of authors expressed herein do not necessarily state or reflect those of the United States Government or any agency thereof.

This report has been reproduced directly from the best available copy.

Available to DOE and DOE contractors from the Office of Scientific and Technical Information, P.O. Box 62, Oak Ridge, TN 37831; prices available from (615) 576-8401.

Available to the public from the National Technical Information Service, U.S. Department of Commerce, 5285 Port Royal Road, Springfield, VA 22161. 


\section{DISCLAIMER}

Portions of this document may be illegible in electronic image products. Images are produced from the best available original document. 


\author{
KEY WORDS: Cesium \\ Illite \\ In-situ remediation \\ Wetlands \\ Mica
}

RETENTION: Permanent

\section{In Situ Remediation of ${ }^{137}$ Cs Contaminated Wetlands Using Naturally Occurring Minerals}

Authors:

Tom G. Hinton, Savannah River Ecology Laboratory

Dan I. Kaplan Westinghouse Savannah River Company

Anna C. Knox, Savannah River Ecology Laboratory

Steve M. Serkiz, Westinghouse Savannah River Company

Date: June 3, 1999

Westinghouse Savannah River Companv Savannah River Site

Aiken. SC 29808

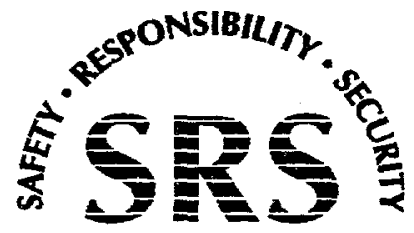



KEY WORDS: Cesium
Illite
In-situ remediation
Wetlands
Mica

RETENTION: Permanent

\section{In Situ Remediation of ${ }^{137}$ Cs Contaminated Wetlands Using Naturally Occurring Minerals}

Authors:

Tom G. Hinton, Savannah River Ecology Laboratory

Dan I. Kaplan Westinghouse Savannah River Company

Anna C. Knox, Savannah River Ecology Laboratory

Steve M. Serkiz, Westinghouse Savannah River Company

Date: June 3, 1999

Westinghouse Savannah River Company Savannah River Site

Aiken. SC 29808

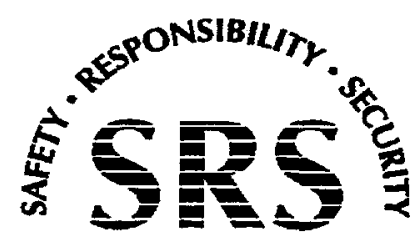


WSRC-TR-99-00229, Rev. 0

June 3, 1999

\section{REVIEWS and APPROVALS}

\section{Author}

D. I. Kaplan, Author

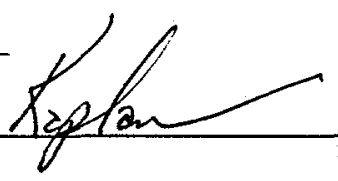

Waste Processing Technology

\section{Approvals/Review}

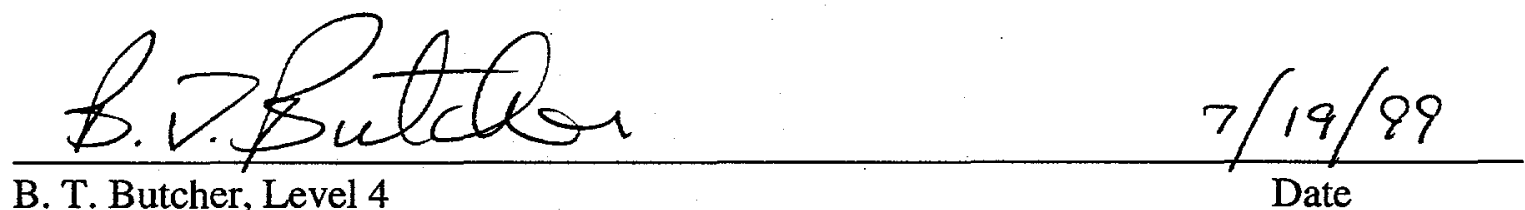

Waste Processing Technology 


\section{TABLE OF CONTENTS}

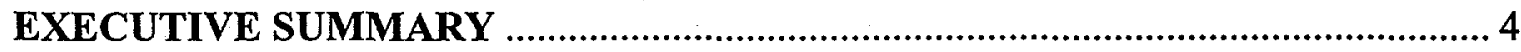

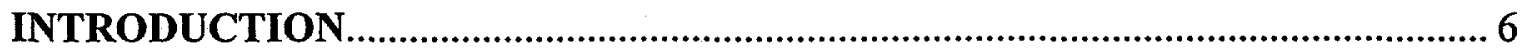

Cesium Contaminated Wetlands .......................................................................... 6

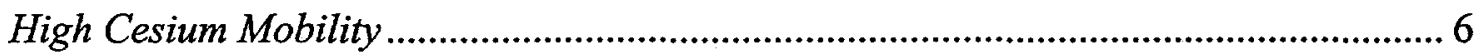

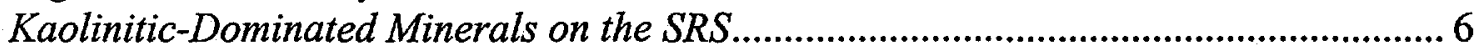

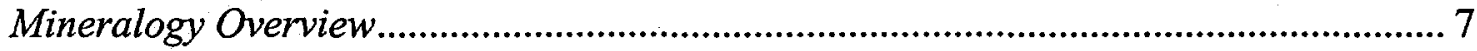

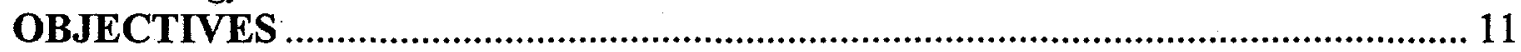

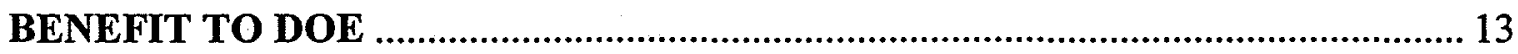

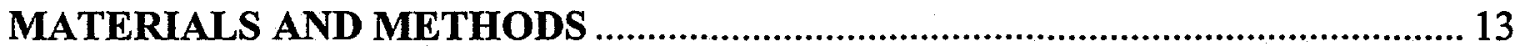

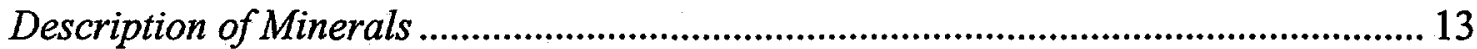

Pretreatment to Remove Surface Coatings on Minerals............................................ 14

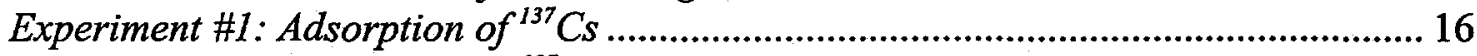

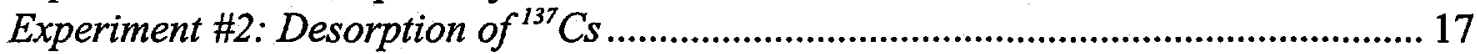

Experiment \#3. Proof of Concept using Pond B sediment ............................................ 18

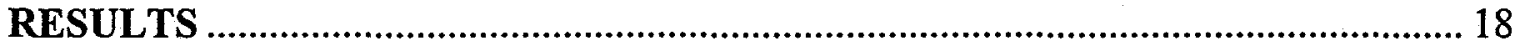

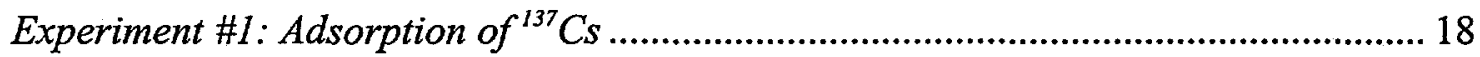

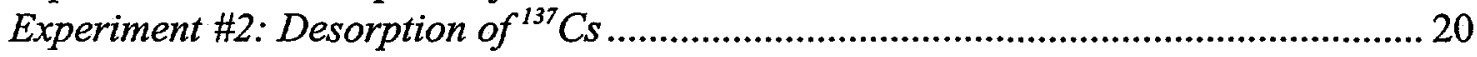

Experiment \#3. Proof of Concept using Pond B sediment .......................................... 21

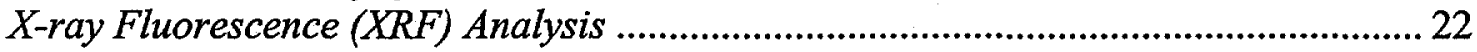

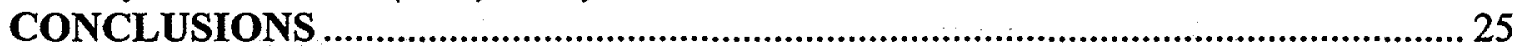

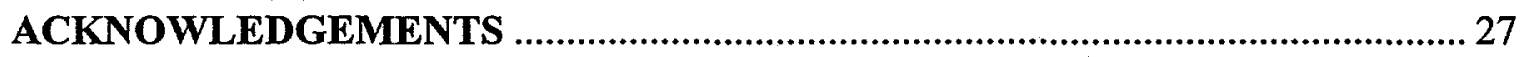

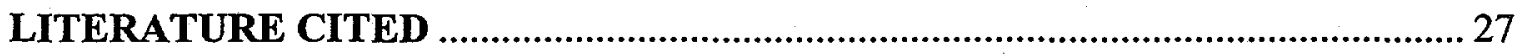

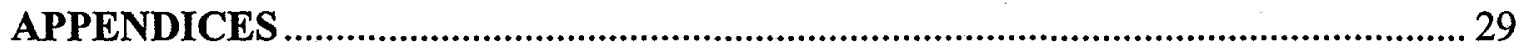




\section{EXECUTIVE SUMMARY}

Over 1,200 hectares (3,000 acres) of wetlands on the Savannah River Site (SRS) are contaminated with $21 \mathrm{TBq}(564 \mathrm{Ci})$ of ${ }^{137} \mathrm{Cs}$ and pose a significant remediation challenge to the Department of Energy (DOE). These wetlands fall under EPA CERCLA regulations and will be closely scrutinized by SCDHEC, stake-holders and environmental groups. Exposure to ${ }^{137} \mathrm{Cs}$ can pose significant human and ecological risks, and yet remediation of the contaminated wetlands is problematic because current remediation technologies destroy the sensitive ecosystem and generate a higher dose to workers.

The problems of contaminated aquatic systems and their associated risks are heightened on the SRS because ${ }^{137} \mathrm{Cs}$ is more mobile here than at any other DOE facility. Reasons for the high bioavailability of ${ }^{137} \mathrm{Cs}$ are thought to be largely due to the low clay fraction of SRS soils, and that the clay mineralogy is dominated by kaolinites coated with iron oxides. The abundance of the clay fraction is important because ${ }^{137} \mathrm{Cs}$ can be bound within the physical structure of clay minerals (Francis and Brinkley 1976), in essence, trapping ${ }^{137} \mathrm{Cs}$ and reducing its bioavailability. Generally, as the clay fraction increases, bioavailability of ${ }^{137} \mathrm{Cs}$ decreases. However, the mineral structure of kaolinite, a $1: 1$ clay, does not bind ${ }^{137} \mathrm{Cs}$ as strongly as 2:1 phyllosilicates such as illites and micas.

Each summer, anaerobic processes in the anoxic sediments of thermally stratified lakes on the SRS lead to a release of ${ }^{137} \mathrm{Cs}$ from the sediments. Although representing only a small percentage of the total ${ }^{137} \mathrm{Cs}$ inventory, the amount released is sufficient to cause measurable activity in all components of the wetlands (e.g., water, plants, aquatic insects, fish, etc.), and is the primary driver in human and ecological risks (Whicker, et al. 1993). Because high Cs mobility on the SRS is thought to be due, in part, to poor sorptive properties of SRS kaolinitic-dominated soils, we tested the hypothesis that an addition of naturally occurring phyllosilicate minerals to wetlands would sequester ${ }^{137} \mathrm{Cs}$ and, thereby, reduce its bioavailablity. In application, the phyllosilicates would be introduced into the wetlands where they would sequester ${ }^{137} \mathrm{Cs}$ in the water column as they settle to the bottom sediments. The phyllosilicates on the bottom sediments would then intercept and sequester ${ }^{137} \mathrm{Cs}$ during its annual summer release from the sediments. If this process works as conceived, the mineral amendments would effectively sequester ${ }^{137} \mathrm{Cs}$ and, thereby significantly reduce its biological uptake.

To ascertain if our concept was fundamentally feasible we designed three experiments to address the following objectives:

- Determine which commercially available clay minerals have high affinities for sorbing ${ }^{137} \mathrm{Cs}$.

- Determine which of those same clay minerals effectively retain ${ }^{137} \mathrm{Cs}$ in the presence of high concentrations of competing cations (e.g., $\mathrm{NH}_{4}^{+}$).

- From the first two experiments, choose clay minerals that are potential amendments and then conduct a proof-of-concept study by testing their ability to reduce ${ }^{137} \mathrm{Cs}$ desorption from contaminated SRS sediments. 
Eleven phyllosilicates were evaluated in this study. Among them were five 2:1 phyllosilicates [one muscovite, one biotite (Mica); a montmorillonite (Smectite); and two vermiculites] and one 1:1 clay mineral (Kaolinite). The most important conclusions from the study were:

- Several minerals (IMt-1, IMt-2, Ward's, VId-1) were shown to exhibit strong sorption (high Cs$K_{d}$ values) and weak Cs-desorption behavior. Cs- $K_{d}$ values of $>10,000 \mathrm{~mL} \mathrm{~g}$ g $^{-1}$ and desorption of $<10 \%$ (under extremely harsh leaching conditions) were observed for these minerals.

- Specific mineral characteristics beneficial to Cs sorption and retention were identified, and should be used when choosing quarried minerals for this technology. Results suggest that quarried minerals should contain illite (not kaolinite, smectite, or biotite) with moderate levels of $\mathrm{K}_{2} \mathrm{O}$, and should contain low concentrations of surface coatings. Because this study was conducted on reference materials, further work is necessary to confirm these beneficial mineral characteristics in commercial material.

- Incremental additions of two minerals (IMt-1 and VId-1) to Pond B sediments, contaminated over 35 years ago, appreciably intercepted and retained desorbed ${ }^{137} \mathrm{Cs}$ in the presence of high levels of added $\mathrm{NH}_{4}^{+}$. These proof-of-concept data revealed a trend of reduced total activity with increasing amounts of phyllosilicate amendment.

The technology proposed addresses a DOE problem that is intractable without new knowledge. The technique may allow DOE to cleanup ${ }^{137} \mathrm{Cs}$-contaminated wetlands in an environmentally acceptable manner--thus, winning the support and praise of Federal and State regulators, stakeholders, and citizen action groups. If successful, this in situ remediation technique could be a wonderful success story for the DOE, in that, through the use of natural materials, DOE might be able to reduce the bioavailability of a major contaminant in an ecosystem that has been difficult to remediate. We think this has the potential to be an appropriate remediation strategy because it would reduce human and ecological risks, yet have no damaging effects on the wetland.

One intention of this study was to provide information regarding a "go/no go" decision for future work. Since the proof-of-concept was successful and several minerals were identified as potential candidates for this technology, a "go" decision was made. Our results suggest a non-intrusive, in situ technology to immobilize ${ }^{137} \mathrm{Cs}$ in sediments may be feasible on the SRS. Future work to take this laboratory proof-of-concept research to the field and to address some applied questions has been proposed. 


\section{INTRODUCTION}

\section{Cesium Contaminated Wetlands}

Numerous aquatic systems on the Savannah River Site (SRS), such as Par Pond and Ponds A, 2, 4, 5 and $\mathrm{B}$, as well as many kilometers of connecting canals, are contaminated with ${ }^{137} \mathrm{Cs}$, ${ }^{90} \mathrm{Sr}$ and isotopes of $\mathrm{Pu}$. Combined, these reservoirs represent over 1,200 hectares (3,000 acres) of contaminated wetlands. Inventories of ${ }^{137} \mathrm{Cs}$ within these aquatic systems (including site streams) have been estimated at $21 \mathrm{TBq}$ (564 Ci, Carlton et al. 1992). Cesium-137 is often the radionuclide of primary concern in these systems because of its long half-life and biological mobility. Cesium's implication to human health was evident during the draw down of Par Pond. Exposure to ${ }^{137} \mathrm{Cs}$ comprised $95 \%$ of the lifetime fatal cancer risks to an adult farmer hypothetically living on the exposed sediments, while ${ }^{90} \mathrm{Sr}$ and $\mathrm{Pu}$ 's contribution to risks were 0.6 and $4.1 \%$, respectively (Whicker et al. 1993).

All of these aquatic sites fall under EPA CERCLA regulations and thus represent a remediation problem to DOE. Remediation of wetlands is particularly problematic because current cleanup technologies for aquatic system are generally destructive to the ecosystem. If cleanup is required, a likely scenario would entail draining the impoundment and either immobilizing the sediments, where $95 \%$ of the radionuclides reside (Whicker et al. 1990), or hauling the sediments off to be buried. These methods would be expensive, would expose workers to inhalation doses, would destroy the associated ecosystems, and would likely invoke negative responses from stake holders, SCDHEC, EPA, and NEPA regulations.

\section{High Cesium Mobility}

The problems of contaminated aquatic systems and their associated risks are heightened on the SRS because ${ }^{137} \mathrm{Cs}$ is more mobile here than at any other DOE facility. Increased ${ }^{137} \mathrm{Cs}$ availability was documented in these systems during the 1960s era of weapons fallout (Whicker and Schultz 1982), and the high mobility of ${ }^{137} \mathrm{Cs}$ still exists today, as is evident by the propensity of ${ }^{137} \mathrm{Cs}$ to be taken up by plants. This propensity can be measured using a concentration ratio (CR), where $\mathrm{CR}=\mathrm{Bq} \mathrm{kg}{ }^{-1}$ dried plant $/ \mathrm{Bq} \mathrm{kg}^{-}$ ' dried soil. The National Council on Radiological Protection and Measurements recommends a default CR to be used in risk calculations of 0.1. In comparison, CRs for the SRS are generally well above 1.0 . Indeed, they are among the highest recorded CRs in the world. Plants from Steel Creek and Par Pond had CRs that ranged from 3 to 7 (Garten and Paine 1977; Pinder et al. 1980), garden vegetables grown on the exposed lake bed of Par Pond had CRs of $6.8 \pm 2.3$ (Seels et al. 1995), and early successional species invading Par Pond's exposed lake bed had extremely high CRs of $14.9 \pm 2.3$ (Hinton et al. 1999). Such large CRs indicate the ease with which ${ }^{137} \mathrm{Cs}$ moves in the lower coastal plain, and in part, indicate why ${ }^{137} \mathrm{Cs}$ can be the critical contaminant when human and ecological risk analyses are conducted for the SRS.

\section{Kaolinitic-Dominated Minerals on the SRS}

Reasons for the high bioavailability of ${ }^{137} \mathrm{Cs}$ are thought to be largely due to the low clay fraction of SRS soils, and that the clay mineralogy is dominated by kaolinites coated with iron oxides. Sediments of 
Par Pond provide a typical example: clay-sized fraction comprised only 1 to $3 \%$ of the textural composition of the sediment (Evans et al. 1983), and $85 \%$ of that was kaolinitic (Ruhe and Matney 1980).

The clay fraction is important because ${ }^{137} \mathrm{Cs}$ can be bound within the physical structure of clay minerals (Francis and Brinkley 1976), in essence, trapping ${ }^{137} \mathrm{Cs}$ and reducing its bioavailability. All factors being equal (e.g., clay mineralogy and competing cation $\left(\mathrm{NH}_{4}{ }^{+}\right)$concentration), as the clay fraction increases, availability of ${ }^{137} \mathrm{Cs}$ generally decreases. The mineral structure of kaolinite (a 1:1 clay), however, does not bind ${ }^{137} \mathrm{Cs}$ as strongly as 2:1 phyllosilicates such as illites and micas. This observation is the basis of our hypothesis that adding phyllosilicate amendments to Cs-contaminated sediments on the SRS may be an effective in situ remediation technique.

\section{Mineralogy Overview}

Unweathered phyllosilicates like micas can be transformed into illites, vermiculites, smectites, or kaolinites depending on the extent to which they have been physically, chemically, and biologically weathered (reviewed by Fanning et al. 1989). The extent of weathering increases in the order of: mica < illite < vermiculite < smectite < kaolinite (Figure 1). Weathering has a profound effect on a number of physical and chemical properties, which in turn have a direct effect on the mineral's propensity and tenacity to sorb Cs. Selected properties of the minerals used in this study are presented in Table 1 and are described below.

The minerals used in this study can be broadly divided into two classes based on their layer structure. Micas, vermiculites, illites, and smectites have a 2:1 layer structure in which tetrahedral (T) and octahedral (O) sheets are arranged in the sequence T-O-T (reviewed by Bailey 1984 and Fanning et al. 1989).

Kaolinite has a 1:1 layer structure arranged in the sequence T-O. The tetrahedral sheets are made up of $\mathrm{Si}$ coordinated with four $\mathrm{O}$ atoms. The octahedral sheets are made up of either trivalent cations (a dioctahedral 2:1 mineral) or divalent cations (a trioctahedral 2:1 mineral). Minerals with 1:1 layer structures do not contain sites that "irreversibly sorb" Cs.

Mica, illite, vermiculite, and smectite carry net negative charges because not all of the cations in the interstices have sufficient positive charge to balance the charge of the oxygen or hydroxyl anions associated with the mineral structures. For micas and illites, most of the charge is derived from substitution of $\mathrm{Al}$ for $\mathrm{Si}$ in the tetrahedral sheets. For most smectites, including montmorillonite, most of the charge is derived from substitution of a divalent cation, usually $\mathrm{Mg}$, for a trivalent cation in the octahedral sheets. Kaolinite derives a very small, barely detectable, amount of its charge from isomorphic substitution. Most of the charge of kaolinite particles comes from the edge sites, whose charge increases with $\mathrm{pH}$. The layer charge is highest for young minerals and less for the older minerals. 


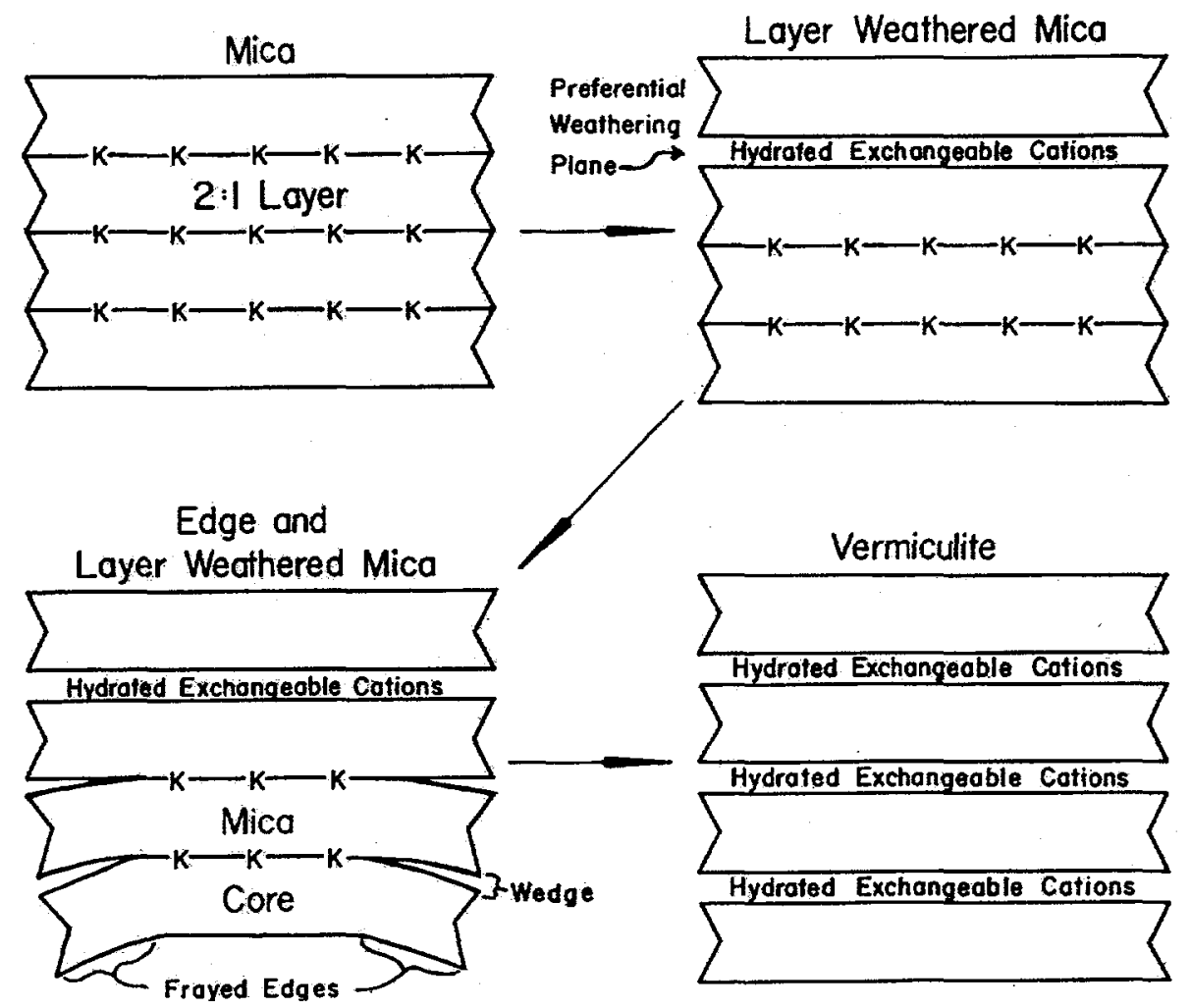

Figure 1. Diagram illustrating the transformation of a mica (with a nonexpanded interlayer containing potassium) to an illite (with frayed edge sites and expanded layers), and an illite to a vermiculite (with expanded interlayers containing hydrated exchangeable cations) (adapted from Fanning et al. 1989).

The negative charge of the layer is balanced by cations that are located in a plane between the 2:1 layer structures. Although mica and illite crystals carry a large negative layer charge, most of the charge is neutalized by tightly held $\mathrm{K}$ ions that are not easily exchanged with other cations. The net negative charge of vermiculites and smectites are balanced with hydrated cations (Figure 1). Due to its low charge, kaolinite particles have relatively few counter ions sorbed to their surfaces and these ions tend to be hydrated divalent cations. 
Table 1. Overview of Properties of Selected Classes of Minerals

\begin{tabular}{|c|c|c|c|c|c|}
\hline & Mica & Illite & Vermiculite & Smectite & Kaolinite \\
\hline $\begin{array}{l}\text { Chemical } \\
\text { Composition } \\
\text { Examples }\end{array}$ & $\begin{array}{l}\mathrm{KAl}_{2}\left(\mathrm{AlSi}_{3} \mathrm{O}_{10}\right)(\mathrm{OH})_{2}- \\
\mathrm{Muscovite} \\
\mathrm{K}(\mathrm{Mg}, \mathrm{Fe})_{3}\left(\mathrm{AlSi} \mathrm{O}_{3} \mathrm{O}_{10}\right) \\
(\mathrm{OH})_{2}-\text { Biotite }\end{array}$ & $\begin{array}{l}[\mathrm{MgFeII})]_{0.25} \mathrm{Al}_{1.75}\left(\mathrm{Al}_{0.5}\right. \\
\left.\mathrm{Si}_{3.5} \mathrm{O}_{10}\right)(\mathrm{OH})_{2}\end{array}$ & Varied & Varied & $\mathrm{Al}_{2} \mathrm{Si}_{2} \mathrm{O}_{5}(\mathrm{OH})_{4}$ \\
\hline Age & Young & $\begin{array}{l}\text { Some substitution of } \\
\text { divalent cations for } \mathrm{K} \text {. } \\
\text { Aged from mica. }\end{array}$ & $\begin{array}{l}\text { Often a weathering } \\
\text { product from } \\
\text { Mica/Illites } \\
\end{array}$ & $\begin{array}{l}\text { Intermediate, often a weathering } \\
\text { product from vermiculites }\end{array}$ & $\begin{array}{l}\text { Old. Often a weathering } \\
\text { product from smectite or } \\
\text { vermiculite }\end{array}$ \\
\hline $\begin{array}{l}\text { Layer } \\
\text { Charge, } \sigma\end{array}$ & $\begin{array}{l}1.0 \text { moles/formula unit. } \\
\text { Lots of substitution in } \\
\text { tetrahedral, little } \\
\text { substitution in octahedral }\end{array}$ & $\begin{array}{l}0.6 \text { to } 0.8 \text { moles/ } \\
\text { formula unit. }\end{array}$ & $\begin{array}{l}0.5 \text { to } 0.9 \\
\text { moles/formula unit }\end{array}$ & $\begin{array}{l}0.6 \text { to } 0.25 \text { moles/formula unit. } \\
\text { Charge formed by } \mathrm{Mg} \text { substitution } \\
\text { for Al in octahedral sheet (e.g., } \\
\text { montmorillonite); Al substitutes for } \\
\text { Si in tetrahedral sheet (e.g., } \\
\text { nontronite) }\end{array}$ & $\begin{array}{l}\text { Very little, only limited } \\
\text { isomorphic substitution } \\
\text { and variable charge } \\
\text { associated with edge sites: } \\
\text { ZPC of edge sites is } \mathrm{pH} \\
\sim 7 \text {. }\end{array}$ \\
\hline $\begin{array}{l}\text { Bonding } \\
\text { between } 2: 1 \\
\text { or } 1: 1 \text { units }\end{array}$ & $\begin{array}{l}\text { Strongest. Because } \\
\text { saturated with } \mathrm{K}^{+} \text {, the } \mathrm{K}^{+} \\
\text {has } \mathrm{r}=1.33 \mathrm{~A} \text {, is small } \\
\text { enough to fit into } \\
\text { ditrigonal hole of } \\
\text { tetrahedral sheet }\end{array}$ & Slightly less than mica & Slightly less than illite & $\begin{array}{l}\text { Varies greatly, depends on } \\
\text { predominant cation in interlayer, } \\
\mathrm{Na}^{+} \text {weak bond, } \mathrm{Al}^{3+} \text { strong bond. }\end{array}$ & $\begin{array}{l}\text { Very strong due to } \mathrm{H} \\
\text { bonding. }\end{array}$ \\
\hline $\begin{array}{l}\text { X-ray d- } \\
\text { spacing for } \\
\text { Mg glycerol } \\
\text { treatment }\end{array}$ & $1 \mathrm{~nm}$ & $1 \mathrm{~nm}$ & $1.4 \mathrm{~nm}$ & $1.8 \mathrm{~nm}$ & $0.7 \mathrm{~nm}$ \\
\hline Tactoid Size & $\begin{array}{l}\text { Thick, because bonds } \\
\text { between tactoids are } \\
\text { strong, } 5 \text { to } 30 \mathrm{~nm}=1 \\
\text { tactoid, Often silt size. }\end{array}$ & Like mica & $\begin{array}{l}\text { Smaller tactoid than } \\
\text { mica. }\end{array}$ & $\begin{array}{l}\text { Varies, unusually thin, } 2 \mathrm{~nm} \text { for } \mathrm{Na} \\
\text { saturated, } 10 \mathrm{~nm} \text { if } \mathrm{Ca} \text { or } \mathrm{Al} \\
\text { saturated. }\end{array}$ & $\begin{array}{l}\text { Thick and long, } 50 \mathrm{~nm} \\
\text { thick, Kaolinite can be } \\
\text { large, silt size. }\end{array}$ \\
\hline $\begin{array}{l}\text { Specific } \\
\text { surface area, } \\
a_{m}\end{array}$ & $\begin{array}{l}\text { Low. Tactoids are large } \\
\text { and little inter-unit area. } \\
70 \text { to } 120 \mathrm{~m}^{2} / \mathrm{g} \text {. }\end{array}$ & $\begin{array}{l}\text { Somewhat larger than } \\
\text { mica by virtue of } \\
\text { smaller particle size. }\end{array}$ & Larger than illite & $\begin{array}{l}\text { Highest, } 100 \text { to } 800 \mathrm{~m}^{2} / \mathrm{g} \text {. Tactoids } \\
\text { can be separated in } \mathrm{Na} \text { saturated } \\
\text { minerals }\end{array}$ & $\begin{array}{l}\text { Low because no interlayer, } \\
5 \text { to } 20 \mathrm{~m}^{2} / \mathrm{g} \text {. }\end{array}$ \\
\hline $\mathrm{CEC}$ & Slighly less than illite & 20 to $40 \mathrm{meq} / \mathrm{kg}$ & $160 \mathrm{meq} / \mathrm{kg}$ & $\begin{array}{l}80 \text { to } 110 \mathrm{meq} / \mathrm{kg} \text {. High because of } \\
\text { high surface area. }\end{array}$ & $\begin{array}{l}\text { Low } 0.3 \text { to } 1 \mathrm{meq} / \mathrm{kg} \text {, } \\
\text { varies with } \mathrm{pH}\end{array}$ \\
\hline
\end{tabular}


The size of an individual particle, or tactoid, is a function of a number of mineral properties. Among the most important is the strength of the bond between the 2:1 or 1:1 units. The stronger this bond is, the larger the particle is likely to be. For the $2: 1$ minerals, mica particles tend to be larger than vermiculites, which in turn are larger than smectites. Kaolinite is commonly a large particle due to hydrogen bonding between 1:1 units. Surface area is inversely related to the tactoid size.

The theoretical cation exchange capacity (CEC) of a mineral is the product of the layer charge and the specific surface area $\left(\mathrm{m}^{2} \mathrm{~g}^{-1}\right)$. Vermiculites have the highest CEC, primarily as a result of its high layer charge (Table 1). Smectites also tend to have a high CEC, largely because of their large specific surface area (especially for Na-saturated particles). Micas have a low CEC due to their relatively low surface area (a result of their non-expanding interlayers). Kaolinite has the lowest CEC as a result of low layer charge and surface area. Since kaolinite is the dominant mineral in SRS sediments, little cation adsorption occurs (Carlton et al. 1992).

\section{Fixation of Radionuclides by Micas and Mlites}

The strong affinity of micas and illites for weakly hydrated, large alkaline cations $\left(\mathrm{K}^{+}, \mathrm{Cs}^{+}\right.$, and $\left.\mathrm{Rb}^{+}\right)$ has found its application in radioactive waste disposal. Of these cations, illites and micas sorb $\mathrm{Cs}^{+}$the strongest. The reason for this is that the nonhydrated $\mathrm{Cs}^{+}$ion fits tightly into the ditrigonal cavities of the tetrahedral sheets (described above). These sorbed $\mathrm{Cs}^{+}$ions are preferentially retained in the presence of hydrated cations, such as $\mathrm{Ca}^{2+}$ or $\mathrm{Mg}^{2+}$, even though the latter typically occur in concentrations that are 5 to 9 orders-of-magnitude greater in the environment. Because of the high affinity of Cs for micas and illites, it is commonly found fixed in micaceous and illitic soils in a form that is nonexchangeable (Francis and Brinkley, 1976).

All the minerals discussed so far have ditrigonal sites; however, not all of the minerals can "irreversibly sorb" Cs. A number of mineralogical factors are responsible for this (Staunton and Roubaud 1997). One important factor is that the minerals must have a sufficiently high unit layer charge to pull the Cs into the ditrigonal cavity in the tetrahedral sheet while forcing the waters of hydration to remain outside the cavity. All kaolinites and smectites, and most vermiculites lack a sufficient unit charge. The other mineralogical property affecting "irreversible sorption" of Cs, is the number of high-energy ditrigonal sites accessible to the aqueous Cs. Micas have few accessible high-energy sites because of the tight bond between the 2:1 units (Figure 1). Illites, by definition, have frayed-edge sites which expose high-energy sorption sites (Figure 1). It should be kept in mind that in addition to these high-energy sites, both illites and micas have planar sites, which sorb Cs via cation-exchange, and edge-sites which sorb Cs via complexation with surface hydroxides. Kaolinite, vermiculites and smectites only have planar and edge sites.

Studies of Cs adsorption on clay minerals are an interesting example of the strong preference micas exhibit for Cs. Tamura (1972) studied the effect of ionic strength on the preference for Cs of several clay minerals. In the suspensions containing only $\mathrm{Cs}$ and no other competing cation, the distribution coefficients $\left(\mathrm{K}_{d}\right)$ for Cs were $52,000,26,000$, and 2,500 for $<2-\mu \mathrm{m}$ vermiculite, illite, and kaolinite, respectively. The 
$K_{d}$ values decreased with decreasing cation exchange capacity of the three minerals $\left(127 \mathrm{cmol} \mathrm{kg}^{-1}\right.$ for vermiculite, $20 \mathrm{cmol} \mathrm{kg}^{-1}$ for illite, and $11 \mathrm{cmol} \mathrm{kg}^{-1}$ for kaolinite). However, when the experiment was performed with $0.1 \mathrm{M} \mathrm{NaCl}$ as a background electrolyte, the $\mathrm{K}_{\mathrm{d}}$ values were 2,$700 ; 28,600$; and 94 , respectively. Clearly, Na competed with Cs for the exchange sites on vermiculite and kaolinite, but on illite Cs remained highly preferred. Comparable results were reported by Staunton and Roubaud (1997) in a study of $\mathrm{Cs}$ exchange with $\mathrm{K}, \mathrm{Na}$, and $\mathrm{Ca}$ on illite and montmorillonite.

\section{OBJECTIVES}

An inventory of ${ }^{137} \mathrm{Cs}$ distribution in Pond B on the SRS revealed that over $95 \%$ of all the cesium was associated with the sediments (Whicker et. al. 1990). In summer, lakes on the SRS thermally stratify and the colder, deeper hypolimnion layer becomes anoxic (Figure 2; Hinton, unpublished data). Anaerobic processes in the anoxic sediments produce $\mathrm{NH}_{4}$, a monovalent cation with a high affinity for displacing ${ }^{137} \mathrm{Cs}$ sorbed to mineral surfaces. This processes are thought to increase the bioavailability of ${ }^{137} \mathrm{Cs}$ (Figure 3a).

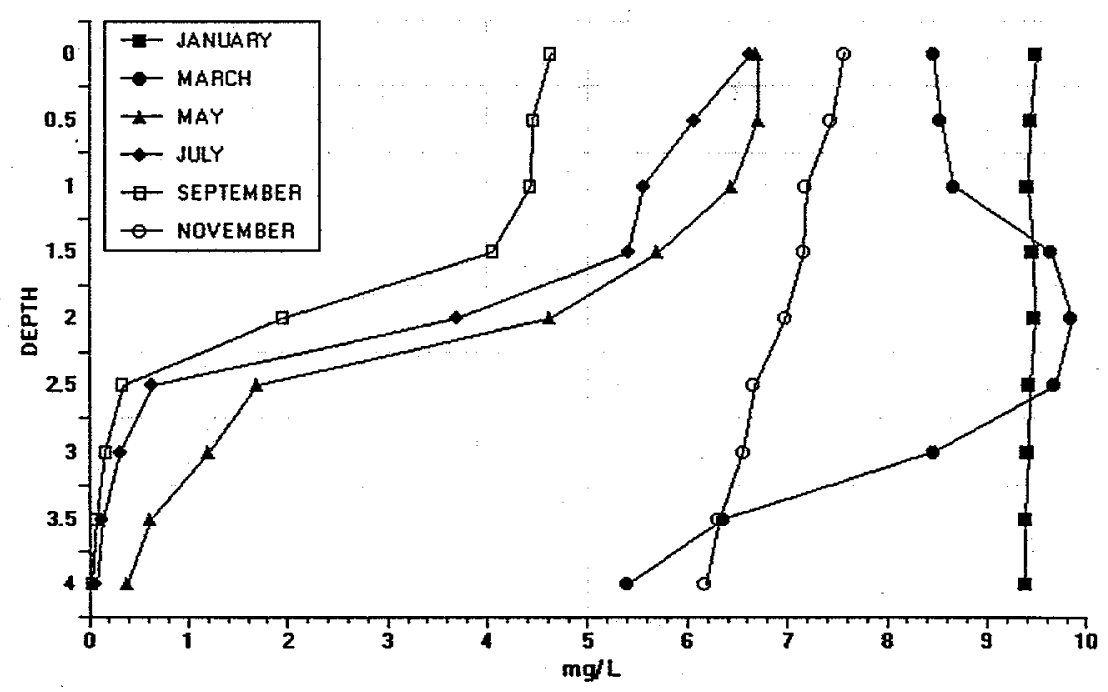

FIGURE 2. Monthly oxygen profiles as a function of depth (m) in Pond 4 on the SRS (Hinton, unpublished data). Low dissolved oxygen concentrations from May to September are thought to contribute to anoxic conditions, a buildup of $\mathrm{NH}_{4}$ in the sediments from anaerobic processes, and a concomitant release of ${ }^{137} \mathrm{Cs}$ from the sediments. 


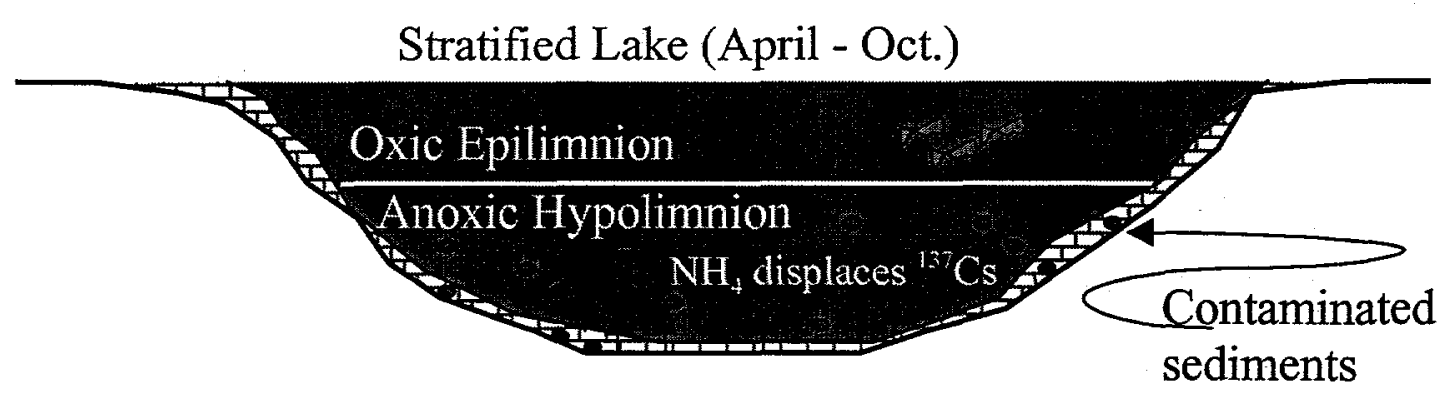

Mixed Lake (Nov. - March)

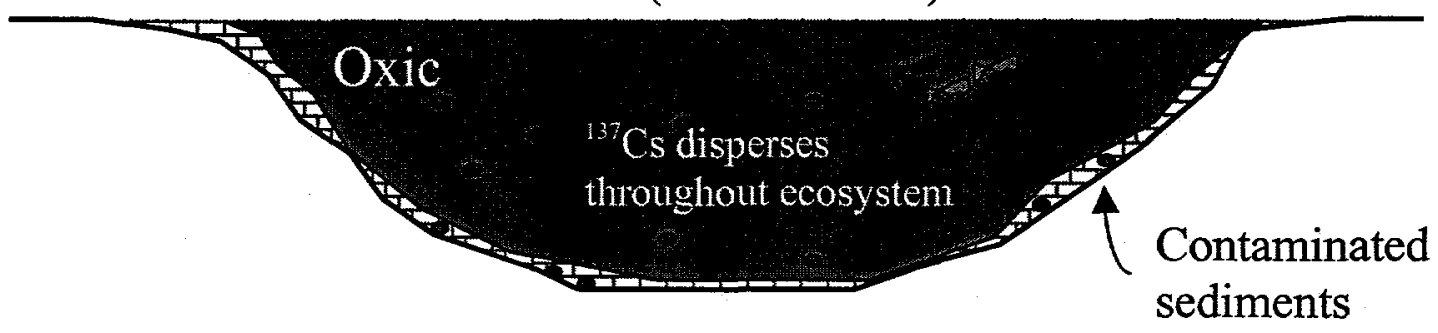

Figure 3a. Annual summer release of ${ }^{137} \mathrm{Cs}$ (depicted by solid circles) from anoxic sediments disperses contamination throughout the aquatic ecosystem in the fall and winter. Release of $\mathrm{Cs}$ is thought to be coupled to a buildup of $\mathrm{NH}_{4}$ in anoxic sediments when the lake is stratified.

Because high Cs mobility on the SRS is due, in part, to a low adsorptive capability of kaoliniticdominated soils, we wanted to test the hypothesis that adding naturally occurring phyllosilicates to wetlands would sequester ${ }^{137} \mathrm{Cs}$ and reduce its bioavailablity. In application, the naturally occurring phyllosilicates would be introduced into the wetlands where they would sorb ${ }^{137} \mathrm{Cs}$ in the water column as they settle to the bottom sediments. The minerals would then intercept and adsorb ${ }^{137} \mathrm{Cs}$ during the annual summer release of ${ }^{137} \mathrm{Cs}$ from the contaminated sediments, effectively sequestering the contaminant and drastically reducing biological uptake (Figure 3 b).

To ascertain if our concept was fundamentally feasible we designed three experiments to address the following objectives:

- Determine which commercially available minerals have high affinities for adsorbing ${ }^{137} \mathrm{Cs}$.

- Determine which of those same clay minerals effectively retain ${ }^{137} \mathrm{Cs}$ when present among ions that have a high affinity for cesium adsorption sites (i.e. $\mathrm{NH}_{4}$ ).

- From the first two experiments, choose minerals that are good candidates as sediment amendments, and then test their ability to reduce the amount of ${ }^{137} \mathrm{Cs}$ desorbed from contaminated SRS sediments. 


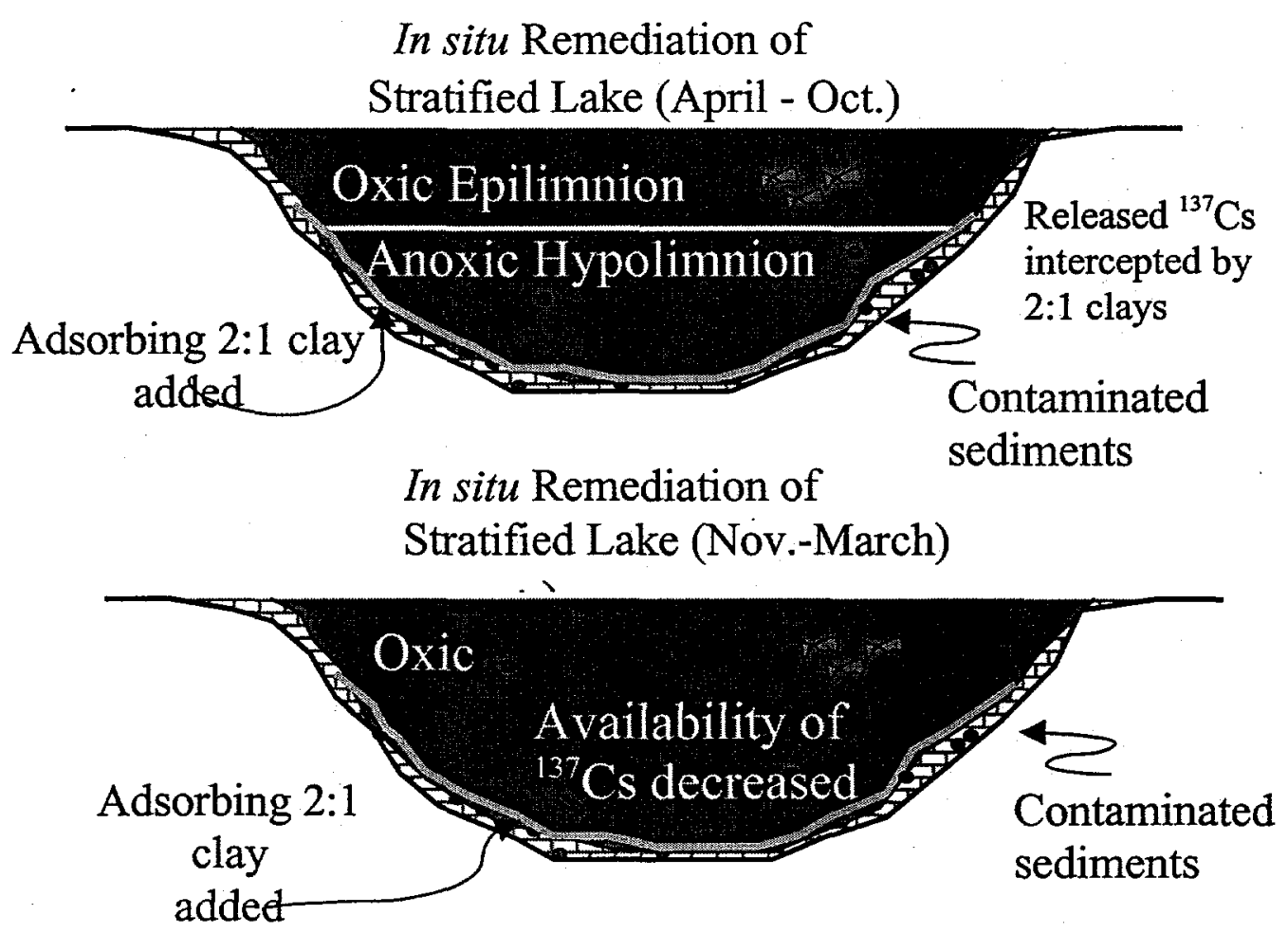

Figure $3 \mathrm{~b}$. Addition of clay mineral amendment intercepts released ${ }^{137} \mathrm{Cs}$ and reduces its availability. Added minerals are illitic with a 2:1 structure that characteristically adsorb Cs much better than the kaolinitic-dominated minerals typically found on the SRS.

\section{BENEFIT TO DOE}

This research is designed to develop proof-of-concept for a new in situ remediation strategy. It addresses a DOE problem that is intractable without new knowledge. The technique may allow DOE to cleanup ${ }^{137} \mathrm{Cs}$-contaminated wetlands in an environmentally acceptable manner--thus, winning the support and praise of Federal and State regulators, stakeholders, and citizen action groups. We think this has the potential to be an appropriate remediation stratagy because it would reduce human and ecological risks, yet have no damaging effects on the wetland. If successful, this in situ remediation technique could be a wonderful success story for the DOE, in that, through the use of natural materials, DOE might be able to reduce the bioavailability of a major contaminant in an ecosystem that has been difficult to remediate.

\section{MATERIALS AND METHODS Description of Minerals}

Eleven clay minerals were evaluated: two micas, two vermiculites, five illites, a kaolinite, and a smectite. The first three minerals were included to evaluate their ability to sorb and desorb Cs. Kaolinite, the dominant clay-size mineral on the SRS, was included to provide a relative value of the sorptive ability of SRS sediments versus those of the other minerals. The montmorillonite was included because it 
provided an end-member to evaluate sorption and desorption trends for the progression: mica, illite, vermiculite, and smectite. General characteristics of these major mineral types are presented in Table 1, followed by characteristics of the specific minerals used in this research (Table 2). The alpha-numeric abbreviations used to refer to individual minerals throughout this report are found in the first column of Table 2.

Surface area of the minerals was obtained from the literature, but data were only available for KGa-2 and SWy-1. We estimated surface area using the BET method (Carter et al. 1986) with a Micromoretics 2000 Accelerated Surface Area and Porosimetry Analysis System. Our measurements of surface area agreed very well with the reported literature (Table 2).

Concentrations of trace elements $(\mathrm{Cr}, \mathrm{K}, \mathrm{Ca}, \mathrm{Ti}, \mathrm{Fe}, \mathrm{Co}, \mathrm{Zn}, \mathrm{As}, \mathrm{Sr}, \mathrm{Zr}, \mathrm{Mo}, \mathrm{Rb}, \mathrm{Cd}, \mathrm{Sn}, \mathrm{Ba}, \mathrm{Ag}, \mathrm{U}$, and $T h$ ) in nontreated minerals were determined using $\mathrm{X}$-ray fluorescence (XRF); the Spectrace 9000 system used three $\mathrm{X}$-ray sources $\left({ }^{109} \mathrm{Cd},{ }^{55} \mathrm{Fe}\right.$, and $\left.{ }^{241} \mathrm{Am}\right)$ and irradiated each sample for $200 \mathrm{sec}$ per source (600 sec total).

\section{Pretreatment to Remove Surface Coatings on Minerals}

Adsorption and desorption of cesium is influenced by material adhering to mineral surfaces. Data on the sorption kinetics of cesium derived from minerals that have had their surface coatings removed facilitate our understanding of the mechanisms that govern cesium kinetics, and also help us in choosing a mineral specific to the remediation requirements of the SRS. Therefore, aliquots of each mineral type were treated with reagents to remove surface coatings of carbonates, free iron oxides and organic carbon using methods detailed by Kunze and Dixon (1986). as required by this method, minerals were first ground and sieved to isolate the 20 - to $53-\mu \mathrm{m}$ size fraction that was then used in all experiments. Carbonates were removed with $7 \mathrm{~mL}$ of $0.5 \mathrm{M}$ sodium acetate (pH 5). Free iron oxides were removed with $20 \mathrm{~mL}$ of $0.3 \mathrm{M}$ Na-citrate and $2.5 \mathrm{~mL}$ of $0.5 \mathrm{M}$ sodium bicarbonate. The reagents and mineral samples were warmed in a water bath to $80^{\circ} \mathrm{C}$ and then $0.25 \mathrm{~g}$ of solid sodium dithionite was added. After stirring for 15 minutes the samples were removed from the water bath and a saturated $\mathrm{NaCl}$ solution was added as needed (approx. 5 $\mathrm{mL}$ ) to flocculate the minerals. The samples were centrifuged, the supernate removed, and a few drops of $1 \mathrm{M} \mathrm{HCl}$ were added to lower $\mathrm{pH}$. Organic carbonate was removed by repeated additions of $30 \% \mathrm{H}_{2} \mathrm{O}_{2}$ until frothing of samples ceased. Samples were then centrifuged and the supernate discarded. Throughout the rest of this report we refer to the mineral samples that had their surface coatings removed as "treated". Experiments were then conducted on the adsorption and desorption of ${ }^{137} \mathrm{Cs}$ by the eleven clay minerals in both treated and nontreated states. 
Table 2. Selected Properties of Clay Minerals Used in this Study

\begin{tabular}{|c|c|c|c|c|c|c|c|}
\hline \multirow[t]{2}{*}{ Sample } & \multirow{2}{*}{$\begin{array}{l}\text { Sample } \\
\text { Location }\end{array}$} & \multirow[t]{2}{*}{ Source } & \multirow{2}{*}{$\begin{array}{l}\text { Octahedral } \\
\text { Sheet }\end{array}$} & \multirow{2}{*}{$\begin{array}{c}\text { Particle } \\
\text { Size }(\mu \mathrm{m})\end{array}$} & \multicolumn{2}{|c|}{ Surface Area SA $\left(\mathrm{m}^{2} / \mathrm{g}\right)$} & \multirow[t]{2}{*}{ Structural formula } \\
\hline & & & & & Measured & Literature & \\
\hline $\begin{array}{l}\text { Kaolinite } \\
(\mathrm{KGa}-2)\end{array}$ & $\begin{array}{l}\text { Warren County, } \\
\text { GA }\end{array}$ & $\begin{array}{l}\text { Clay Min. Soc., } \\
\text { Denver, CO }\end{array}$ & $\begin{array}{c}\mathrm{Di}- \\
\text { octahedral }\end{array}$ & $\begin{array}{l}\text { As received } \\
<53\end{array}$ & 22.8 & $23.5^{(a)}$ & $\mathrm{Al}_{2} \mathrm{Si}_{2} \mathrm{O}_{5}(\mathrm{OH})_{4}^{\left({ }^{(b)}\right.}$ \\
\hline $\begin{array}{l}\text { Na-Montmorill- } \\
\text { onite (SWy-1) }\end{array}$ & $\begin{array}{l}\text { Crook County, } \\
\text { WY }\end{array}$ & $\begin{array}{l}\text { Clay Min. Soc., } \\
\text { Denver, CO }\end{array}$ & $\begin{array}{c}\text { Di- } \\
\text { octahedral }\end{array}$ & 53 to 20 & 31.9 & $31.8^{(a)}$ & $\begin{array}{l}\mathrm{M}_{0.70}^{+}\left[\left(\mathrm{Al}_{2.99} \mathrm{Fe}_{0.42}^{3+} \mathrm{Fe}_{0.01}^{2+}\right)\right) \mathrm{Si}_{7.97} \\
\left.\left.\mathrm{Al}_{0.03}\right) \mathrm{O}_{20}(\mathrm{OH})_{4}\right]^{(\mathrm{b})}\end{array}$ \\
\hline Illite (IMt-1) & Silver Hill, MT & $\begin{array}{l}\text { Clay Min. Soc., } \\
\text { Denver, CO }\end{array}$ & $\begin{array}{c}\text { Di- } \\
\text { octahedral }\end{array}$ & 53 to 20 & 32.7 & & \\
\hline Illite (IMt-2) & Silver Hill, MT & $\begin{array}{l}\text { Clay Min. Soc., } \\
\text { Denver, CO }\end{array}$ & $\begin{array}{c}\text { Di- } \\
\text { octahedral }\end{array}$ & 53 to 20 & 28 & & \\
\hline Illite (Ward's) & $\begin{array}{l}\text { Monroe } \\
\text { County, NY }\end{array}$ & $\begin{array}{l}\text { Ward's, } \\
\text { Rochester, NY }\end{array}$ & $\begin{array}{c}\text { Di- } \\
\text { octahedral }\end{array}$ & 53 to 20 & 26.4 & & $\begin{array}{l}\left(\mathrm{K}, \mathrm{H}_{3} \mathrm{O}\right)(\mathrm{Al}, \mathrm{Mg}, \mathrm{Fe})_{2}(\mathrm{Si}, \mathrm{Al})_{4} \mathrm{O}_{10} \\
{\left[(\mathrm{OH})_{2}, \mathrm{H}_{2} \mathrm{O}\right]{ }^{(\mathrm{c})}}\end{array}$ \\
\hline Illite (I-API- 35) & Gray Shale & $\begin{array}{l}\text { Am. Petroleum } \\
\text { Instit., Wash., DC }\end{array}$ & $\begin{array}{l}\text { Di- } \\
\text { octahedral }\end{array}$ & 53 to 20 & 70.3 & & \\
\hline $\begin{array}{l}\text { Illite } \\
\text { (I-API-Green) }\end{array}$ & Green Shale & $\begin{array}{l}\text { Am. Petroleum } \\
\text { Instit., Wash., DC }\end{array}$ & $\begin{array}{l}\text { Di- } \\
\text { octahedral }\end{array}$ & 53 to 20 & 26.9 & & \\
\hline $\begin{array}{l}\text { Vermiculite } \\
(\mathrm{VTx}-1)\end{array}$ & $\begin{array}{l}\text { Llano County, } \\
\text { TX }\end{array}$ & $\begin{array}{l}\text { Clay Min. Soc., } \\
\text { Denver, CO }\end{array}$ & $\begin{array}{l}\text { Tri- } \\
\text { octahedral }\end{array}$ & 53 to 20 & 39.5 & & $\begin{array}{l}\mathrm{Mg}^{2+}{ }_{0.80} \mathrm{Ca}^{2+}{ }_{0.10} \mathrm{Na}^{+}{ }_{0.04} \mathrm{~K}_{0.01}^{+}\left[\left(\mathrm{Mg}_{5.50} \mathrm{Al}_{0.33} \mathrm{Fe}_{0.04}\right.\right. \\
\left.\left.\mathrm{Ti}_{0.04}\right)\left(\mathrm{Si}_{5.89} \mathrm{Al}_{2.31}\right) \mathrm{O}_{20}(\mathrm{OH})_{4}\right]^{(\mathrm{b})}\end{array}$ \\
\hline $\begin{array}{l}\text { Vermiculite } \\
\text { (VId-1) }\end{array}$ & $\begin{array}{l}\text { Washington } \\
\text { County, ID }\end{array}$ & $\begin{array}{l}\text { Clay Min. Soc., } \\
\text { Denver, CO }\end{array}$ & & 53 to 20 & 28.2 & & \\
\hline Muscovite & $\begin{array}{l}\text { Lord Hill, near } \\
\text { Stoneham, ME }\end{array}$ & $\begin{array}{l}\text { Ward's, } \\
\text { Rochester, NY }\end{array}$ & $\begin{array}{c}\text { Di- } \\
\text { octahedral }\end{array}$ & 53 to 20 & 9 & & $\mathrm{~K}\left(\mathrm{Si}_{3} \mathrm{Al}\right) \mathrm{Al}_{2} \mathrm{O}_{10}(\mathrm{OH})_{2}{ }^{(c)}$ \\
\hline Biotite & $\begin{array}{l}\text { Bancroft, ON, } \\
\text { Canada }\end{array}$ & $\begin{array}{l}\text { Ward's, } \\
\text { Rochester, NY }\end{array}$ & $\begin{array}{c}\text { Tri- } \\
\text { octahedral }\end{array}$ & 53 to 20 & 5.1 & & $\mathrm{~K}(\mathrm{Mg}, \mathrm{Fe})_{3}\left(\mathrm{Si}_{3} \mathrm{Al}\right) \mathrm{O}_{10}(\mathrm{OH})_{2}{ }^{(\mathrm{c})}$ \\
\hline
\end{tabular}

a. Web page of Clay Mineral Society - Http:/www.missouri.edu/ geoscjy/SourceClay/chem.html.

b. Weiss,Jr., 1990.

c. Dixon and Weed, 1989 
Experiment \#I: Adsorption of ${ }^{137} \mathrm{Cs}$

The goal of this experiment was to compare the ability of the various minerals to adsorb ${ }^{137} \mathrm{Cs}$. Comparisons were made among the 11 minerals, and each mineral sample had treated aliquots in which the surface coatings were removed, as well as nontreated ones. Each treatment was replicated three times. The experiment was conducted in $50-\mathrm{mL}$ centrifuge tubes, each containing $0.15 \mathrm{~g}$ of clay mineral. All samples were equilibrated overnight in $28 \mathrm{~mL}$ of filtered $(0.45 \mu \mathrm{m})$ water from Pond B and then centrifuged ( $4500 \mathrm{rpm}, 30$ minutes). The equilibration step was repeated three times. The chemical composition of Pond B water is shown in Table 3. Adsorption of ${ }^{137} \mathrm{Cs}$ was initiated by adding $10 \mathrm{~mL}$ of ${ }^{137} \mathrm{Cs}$-spiked Pond B water to each sample. The spiked Pond B solution contained $1718 \mathrm{~Bq} \mathrm{~mL}{ }^{-1}(46 \mathrm{nCi}$ $\mathrm{mL}^{-1}$ ) of ${ }^{137} \mathrm{Cs}$. Trace levels of ${ }^{137} \mathrm{Cs}$ were used to minimize competition among the dissolved $\mathrm{Cs}$ ions for surface sorption sites. Samples were agitated for one week with an automatic shaker, centrifuged, and a 5$\mathrm{mL}$ aliquot removed for ${ }^{137} \mathrm{Cs}$ analysis. Activity of the aliquot was determined on a Packard AutoGamma $\mathrm{NaI}$ dectector with an efficiency of $17.5 \%$. The amount of ${ }^{137} \mathrm{Cs}$ adsorbed to the clay samples was estimated by comparing the activity of ${ }^{137} \mathrm{Cs}$ added at the beginning of the experiment to the activity in the aliquot removed one week later. The propensity for cesium to bind to minerals can be quantified with a parameter that measures the distribution of ${ }^{137} \mathrm{Cs}$ in mineral materials compared to the distribution in water. The parameter, termed a distribution coefficient $\left(\mathrm{K}_{\mathrm{d}}\right)$, is expressed as:

$$
K_{d}=\frac{\left(A_{\text {spike }} \times V_{\text {spike }}\right)-A_{\text {final }}\left(V_{\text {spike }}+V_{\text {int erstitial pretreatment }}\right)}{A_{\text {final }} \times M_{\text {clay }}}
$$

where $A_{\text {spike }}$ and $V_{\text {spike }}$ are the activity concentration $\left(\mathrm{Bq} \mathrm{mL} \mathrm{mL}^{-1}\right)$ and volume $(\mathrm{mL})$, respectively, of the ${ }^{137} \mathrm{Cs}$ solution added to the clay sample; $V_{\text {interstital pretreatment }}$ is the volume of the interstitial solution left after the third equilibration wash $(\mathrm{mL}) ; M_{\text {clay }}$ is the clay mass (g); and $A_{\text {final }}$ is the ${ }^{137} \mathrm{Cs}$ activity concentration in the aliquot removed at the end of the experiment $\left(\mathrm{Bq} \mathrm{mL}^{-1}\right)$. Data were normalized on a mass and surface area basis.

Table 3. Analysis of Pond B Surface Water.

\begin{tabular}{|c|c|c|c|c|c|c|c|c|c|c|c|}
\hline $\begin{array}{l}\text { Sample } \\
\text { I.D. }\end{array}$ & Date & $\mathrm{pH}$ & $\begin{array}{c}\mathrm{P} \\
(\mathrm{mg} / \mathrm{L})\end{array}$ & $\begin{array}{c}\mathrm{Na} \\
(\mathrm{mg} / \mathrm{L}\end{array}$ & $\begin{array}{c}\mathrm{K} \\
(\mathrm{mg} / \mathrm{L})\end{array}$ & $\begin{array}{l}\mathrm{Ca} \\
(\mathrm{mg} / \mathrm{L})\end{array}$ & $\begin{array}{l}\mathrm{Mg} \\
(\mathrm{mg} / \mathrm{L})\end{array}$ & $\begin{array}{c}\mathrm{Mn} \\
(\mathrm{mg} / \mathrm{L})\end{array}$ & $\begin{array}{c}\mathrm{Fe} \\
(\mathrm{mg} / \mathrm{L})\end{array}$ & $\begin{array}{c}\mathrm{Al} \\
(\mathrm{mg} / \mathrm{L})\end{array}$ & $\begin{array}{c}\mathrm{B} \\
(\mathrm{mg} / \mathrm{L})\end{array}$ \\
\hline PB-1 & $1 / 24 / 95$ & 6.95 & $<0.06$ & 1.7 & $<0.40$ & 1.23 & 0.43 & $<0.005$ & 0.09 & 0.07 & $<0.01$ \\
\hline PB-2 & $3 / 30 / 95$ & 6.04 & $<0.06$ & 1.6 & $<0.40$ & 1.02 & 0.36 & 0.01 & 0.17 & 0.03 & $<0.01$ \\
\hline WS.B1297 & $12 / 9 / 97$ & 6.35 & $<0.06$ & 1.5 & $<0.20$ & 0.54 & 0.29 & $<0.001$ & 0.27 & $<0.03$ & $<0.01$ \\
\hline WS.B5 & $11 / 20 / 98$ & 6.34 & $<0.06$ & 1.4 & $<0.20$ & 0.91 & 0.35 & 0.09 & 0.55 & $<0.03$ & 0.01 \\
\hline
\end{tabular}




\section{Experiment \#2: Desorption of ${ }^{137} \mathrm{Cs}$}

The tenacity with which cesium binds to mineral surfaces varies among mineral types. Cesium can be desorbed from minerals by competing ions. An effective mineral amendment should strongly bind cesium and have minimum desorption. Ammonium ions are particularly affective at displacing cesium from the frayed edged sites of clay minerals. The purpose of Experiment $\# 2$ was to compare the ease at which ${ }^{137} \mathrm{Cs}$ desorbs from the candidate minerals in the presence of competing $\mathrm{NH}_{4}{ }^{+}$.

Our desorption experiment was conducted on the same samples used in Experiment 1. Once the adsorption step was completed, the minerals were separated from the aqueous phase by centrifugation, and the interstitial liquid was removed by flushing the sediments with unspiked Pond B water. We then added $20 \mathrm{~mL}$ of $0.1 \mathrm{M} \mathrm{NH}_{4} \mathrm{Cl}$ and allowed the samples to mix on an automatic shaker for two weeks. This high $\mathrm{NH}_{4}{ }^{+}$concentration exceeds by many orders of magnitude the expected $\mathrm{NH}_{4}{ }^{+}$concentrations on SRS surface waters, which is generally about $5 \mathrm{mg} / \mathrm{L} \mathrm{NH}_{4}{ }^{+}$. This high $\mathrm{NH}_{4}{ }^{+}$concentration was selected to provide a worst case scenario. One potential problem with using such a high $\mathrm{NH}_{4}^{+}$concentration is that it may cause the mineral interlayers to collapse, thereby locking the sorbed Cs within the 2:1 structure. Based on results from Evans et al. (1983), it seems unlikely that this occurred in our study. Evans et al. (1983) showed a linear amount of desorption as the amount of $\mathrm{NH}_{4}^{+}$added was increased from $10^{-6}$ to $10^{-3}$ M. $\mathrm{Had} \mathrm{NH}_{4}{ }^{+}$caused the mineral interlayer to collapse, then the amount of $\mathrm{Cs}$ desorbed would have remained constant or decreased upon the addition of elevated concentrations of $\mathrm{NH}_{4}^{+}$. Following centrifugation, $5 \mathrm{~mL}$ of solution were removed and assayed for ${ }^{137} \mathrm{Cs}$ activity.

The amount of ${ }^{137} \mathrm{Cs}$ desorbed by each mineral was calculated as a percentage using equations 2,3 and 4. Data were normalized on a surface area and mass basis.

$$
\begin{gathered}
\% \text { desorbed }=\left(\frac{A_{\text {desorbed }}}{A_{\text {adsorbed }}}\right) \times 100 \\
A_{\text {adsorbed }}=\left(A_{\text {spike }}-A_{A}\right)\left(\frac{V_{\text {spike }}+V_{\text {int erstitial pretreatment }}}{M_{\text {clay }}}\right) \\
A_{\text {desorbed }}=\frac{A_{D}\left(V_{N H_{r} C l}+V_{\text {inerstitial adsorption }}\right)-A_{A}\left(V_{\text {int erstitial adsorption }}\right)}{M_{\text {clay }}}
\end{gathered}
$$


where:

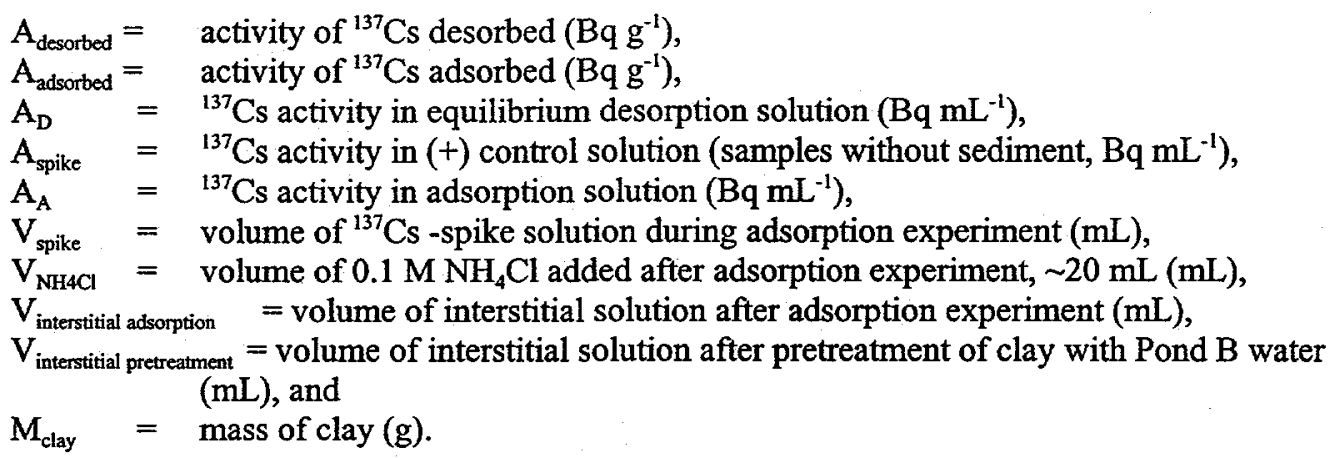

\section{Experiment \#3. Proof of Concept using Pond B sediment}

Experiment \#3 was a test of our hypothesis that the addition of 2:1 clays to a kaolinite-dominated system, such as occurs on the SRS, would reduce the availability of ${ }^{137} \mathrm{Cs}$. We used sediments from Pond $\mathrm{B}$, an aquatic system that was contaminated with fission products 35 year ago, and incrementally added phyllosilicate minerals to see how the mobility of ${ }^{137} \mathrm{Cs}$ was affected. From the results of the first two experiments we chose two minerals with high affinities for adsorbing ${ }^{137} \mathrm{Cs}$ (i.e. large $\mathrm{Kd}$ values), and low affinities for ${ }^{137} \mathrm{Cs}$ to desorb. An illite (IMt-1) and vermiculite (VId-1) were used. Each mineral was added to $20 \mathrm{~g}$ of moist Pond B sediment at three levels $(0.01,0.1$ and $1.0 \mathrm{~g})$. Desorption of ${ }^{137} \mathrm{Cs}$ from the Pond $\mathrm{B}$ sediments and from the mineral amended sediments were compared. Our hypothesis was that desorption would be reduced as the percentage of mineral amendments increased. Desorption was promoted by adding $20 \mathrm{mg} \mathrm{L}^{-1} \mathrm{NH}_{4}^{+}$to the Pond $\mathrm{B}$ equilibrating solution. The experiment was conducted in $50 \mathrm{~mL}$ centrifuge tubes, with two replicates per treatment. Minerals were not preequilibrated with Pond $\mathrm{B}$ water. Samples were shaken for 2 weeks, centrifuged, and $5 \mathrm{~mL}$ of $0.45-\mu \mathrm{m}$ filtered solution removed for ${ }^{137} \mathrm{Cs}$ analysis. Five experimental controls, all containing Pond $\mathrm{B}$ water spiked with $20 \mathrm{mg} \mathrm{L}^{-1} \mathrm{NH}_{4}{ }^{+}$, were used: 0.1 gram aliquots of the two minerals without Pond B sediment; Pond B sediments alone without mineral amendments; Pond B water without minerals and without sediment; and a chemical blank. The $5 \mathrm{~mL}$ removed from each sample were evaporated down, resuspended in $1 \mathrm{~mL}$ of $0.5 \mathrm{M} \mathrm{HCl}$ and added to $19 \mathrm{~mL}$ of liquid scintillation cocktail (Optiphase Trisafe). ${ }^{137} \mathrm{Cs}$ activities were determined on an ultra low-level liquid scintillation system (Quantulus, Wallac) whose lower level of detection (based on ${ }^{90} \mathrm{Sr}$ ) was $0.12 \mathrm{~Bq}$ over a count period of 6 hours.

\section{RESULTS}

Experiment \#1: Adsorption of ${ }^{137} \mathrm{Cs}$

An experiment was conducted to evaluate the extent to which ${ }^{137} \mathrm{Cs}$ adsorbed to eleven minerals under treatments in which the surface coatings were removed, as well as, on nontreated samples. The type of mineral had a significant effect on the extent of adsorption that took place with the nontreated (Table 4) and treated (Table 5) minerals (additional information presented in Appendix A). For the non-treated 
minerals, the micas, illites, vermiculites and montmorillonite had significantly larger $\mathrm{K}_{d}$ values than kaolinite ( $\mathrm{P}<0.05$; Table 4). Two illites, IMt-1 and Ward's, had signficantly greater $\mathrm{K}_{\mathrm{d}}$ values than the remaining minerals $(\mathrm{P}<0.001)$. The two vermiculites (VId-1 and VTx-1) had $\mathrm{K}_{d}$ values that differed by two orders-of-magnitude. The cause for this difference is that the VId-1 vermiculite almost certainly contained some fraction of mica or illite (discussed below).

Table 4. Cesium $K_{d}$ and Percent Desorption Values of Non-treated Minerals ${ }^{(2)}$

\begin{tabular}{|c|c|c|c|c|}
\hline Mineral & $\begin{array}{c}\mathrm{K}_{\mathrm{d}} \\
\pm \text { Std. Dev. } \\
(\mathrm{mL} / \mathrm{g})\end{array}$ & $\begin{array}{l}\text { \% Desorption } \\
\pm \text { Std. Dev. } \\
\text { (\%, wt/wt) }\end{array}$ & $\begin{array}{c}\mathrm{K}_{\mathrm{d} \text {-surface }} \\
\pm \text { Std. Dev. } \\
\left(\mathrm{mL} / \mathrm{m}^{2}\right)\end{array}$ & $\begin{array}{c}\%_{\text {Desorption }} \text { surface } \\
\pm \text { Std. Dev. } \\
\left(\% \text {, wt/area; } \mathrm{g} / \mathrm{m}^{2}\right)\end{array}$ \\
\hline Kaolinite (KGa-2) & $\begin{array}{c}238 \pm 7 \\
(\mathrm{~F})\end{array}$ & $\begin{array}{l}117 \pm 55 \\
\text { (D) }\end{array}$ & $\begin{array}{c}10 \pm 0 \\
(F)\end{array}$ & $\begin{array}{l}5.14 \pm 2.40 \\
\text { (D) }\end{array}$ \\
\hline Na-Mont. (SWy-2) & $\begin{array}{c}728 \pm 66 \\
\text { (E) }\end{array}$ & $\begin{array}{c}90 \pm 9 \\
(A, C, D)\end{array}$ & $\begin{array}{c}23 \pm 2 \\
\text { (F) }\end{array}$ & $\begin{array}{c}2.82 \pm 0.27 \\
(\mathrm{D}, \mathrm{E})\end{array}$ \\
\hline Illite (IMt-1) & $\begin{array}{c}60914 \pm 1154 \\
\text { (C) }\end{array}$ & $\begin{array}{l}21 \pm 1 \\
(B)\end{array}$ & $\begin{array}{c}1863 \pm 353 \\
(B, C)\end{array}$ & $\begin{array}{c}0.63 \pm 0.04 \\
(\mathrm{~A})\end{array}$ \\
\hline Illite (IMt-2) & $\begin{array}{c}10728 \pm 3340 \\
\text { (A) }\end{array}$ & $\begin{array}{c}24 \pm 6 \\
\text { (B) }\end{array}$ & $\begin{array}{c}383 \pm 119 \\
(\mathrm{~B}, \mathrm{D})\end{array}$ & $\begin{array}{c}0.86 \pm 0.20 \\
\text { (A) }\end{array}$ \\
\hline Illite (Ward's) & $\begin{array}{c}29097 \pm 10515 \\
(\mathrm{~B}, \mathrm{C}, \mathrm{D})\end{array}$ & $\begin{array}{c}20 \pm 4 \\
\text { (b) }\end{array}$ & $\begin{array}{c}1102 \pm 398 \\
(\mathrm{~B}, \mathrm{E})\end{array}$ & $\begin{array}{c}0.77 \pm 0.13 \\
\text { (A) }\end{array}$ \\
\hline Illite (I-API-35) & $\begin{array}{c}9323 \pm 1035 \\
\text { (A) }\end{array}$ & $\begin{array}{c}51 \pm 7 \\
(\mathrm{~A})\end{array}$ & $\begin{array}{c}133 \pm 15 \\
(\mathrm{~A})\end{array}$ & $\begin{array}{c}0.73 \pm 0.10 \\
(\mathrm{~A})\end{array}$ \\
\hline Illite (I-API-Green) & $\begin{array}{c}20841 \pm 2449 \\
(\mathrm{~A}, \mathrm{~B})\end{array}$ & $\begin{array}{l}32 \pm 3 \\
(\mathrm{~A}, \mathrm{~B})\end{array}$ & $\begin{array}{c}775 \pm 91 \\
\text { (B) }\end{array}$ & $\begin{array}{c}1.18 \pm 0.11 \\
(\mathrm{~A}, \mathrm{~B})\end{array}$ \\
\hline Vermiculite (VId-1) & $\begin{array}{c}21959 \pm 10691 \\
\text { (A) }\end{array}$ & $\begin{array}{c}4 \pm 0 \\
(\mathrm{E})\end{array}$ & $\begin{array}{c}779 \pm 379 \\
\text { (B) }\end{array}$ & $\begin{array}{c}0.15 \pm 0.01 \\
(\mathrm{~F})\end{array}$ \\
\hline Vermiculite (VTx-1) & $\begin{array}{c}623 \pm 47 \\
(\mathrm{E})\end{array}$ & $\begin{array}{c}69 \pm 11 \\
(\mathrm{~A}, \mathrm{D})\end{array}$ & $\begin{array}{c}16 \pm 1 \\
(\mathrm{~F})\end{array}$ & $\begin{array}{c}1.75 \pm 0.28 \\
(\mathrm{~B}, \mathrm{E})\end{array}$ \\
\hline Mica (Muscovite) & $\begin{array}{c}1978 \pm 320 \\
(\mathrm{G})\end{array}$ & $\begin{array}{l}116 \pm 11 \\
\text { (D) }\end{array}$ & $\begin{array}{c}220 \pm 36 \\
(\mathrm{~A}, \mathrm{D})\end{array}$ & $\begin{array}{c}12.94 \pm 1.25 \\
(\mathrm{C})\end{array}$ \\
\hline Mica (Biotite) & $\begin{array}{c}13464 \pm 8362 \\
(\mathrm{~A}, \mathrm{D})\end{array}$ & $\begin{array}{c}53 \pm 3 \\
(\mathrm{~A}, \mathrm{~B}, \mathrm{C}) \\
\end{array}$ & $\begin{array}{c}2640 \pm 1640 \\
(C, E)\end{array}$ & $\begin{array}{c}10.41 \pm 0.68 \\
(\mathrm{C})\end{array}$ \\
\hline
\end{tabular}

(a) Means within a column followed by the same capital letter are not significantly different at the $5 \%$ level of probability according to Bonferroni's multiple comparison method (Neter and Wasserman, 1974).

It was anticipated that by removing the surface coatings the dissolved ${ }^{137} \mathrm{Cs}$ would come into contact with the dominant mineral phase, and therefore its adsorptive behavior would be more predictive based on mineralogical considerations. Analyses showed that like the results from the nontreated samples the kaolinite and the montmorillonite had the lowest $\mathrm{K}_{d}$ values, except for the VTx-1 vermiculite (Table 5). The illites tended to have higher $K_{d}$ values than either the micas or the VTx-1 vermiculite. The VId-1 vermiculite had an unexpectedly high $K_{d}$ value, as was the case with the nontreated samples (Table 4).

Since adsorption processes are surface processes, the $K_{d}$ values were normalized by surface area. This was accomplished by simply dividing the $K_{d}\left(\mathrm{~mL} \mathrm{~g}^{-1}\right)$ values in Table 4 by the specific surface area values in Table 2. The trends between the traditional (weight normalized) and surface-normalized $K_{d}$ values were quite similar with one important difference. Both mica $\mathrm{K}_{\mathrm{d} \text {-surf }}$ values were appreciably greater than their respective traditional $K_{d}$ values. This may be an important finding for later development of this 
technology. It may prove necessary to use large particles, silt size, when remediating a Cs-contaminated wetland to limit the extent that suspended contaminated particles disperse through a wetland. The high $\mathrm{K}_{\mathrm{d}-\text { sur }}$ would allow larger particles to be used without a substantial decrease in sorption efficiency.

Table 5. Cesium $K_{d}$ and Percent Desorption Values of Treated Minerals ${ }^{(a)}$

\begin{tabular}{|c|c|c|c|c|}
\hline Mineral & $\begin{array}{c}\mathrm{K}_{\mathrm{d}} \\
\pm \text { Std. Dev. } \\
(\mathrm{mL} / \mathrm{g})\end{array}$ & $\begin{array}{c}\% \text { Desorption } \\
\pm \text { Std. Dev. } \\
(\%, w t / w t)\end{array}$ & $\begin{array}{c}\mathrm{K}_{\mathrm{d} \text {-surface }} \\
\pm \mathrm{Std} . \text { Dev. } \\
\left(\mathrm{mL} / \mathrm{m}^{2}\right)\end{array}$ & $\begin{array}{c}\% \text { Desorption }_{\text {surface }} \pm \\
\text { Std. Dev. } \\
\left(\% \text {, wt/area; } g / \mathbf{m}^{2}\right)\end{array}$ \\
\hline Kaolinite (KGa-2) & $\begin{array}{l}335 \pm 141 \\
\text { (D) }\end{array}$ & $\begin{array}{c}106 \pm 29 \\
(\mathrm{C})\end{array}$ & $\begin{array}{c}15 \pm 6 \\
(\mathrm{G})\end{array}$ & $\begin{array}{c}4.63 \pm 1.26 \\
\text { (B) }\end{array}$ \\
\hline Na-Mont. (SWy-2) & $\begin{array}{c}2722 \pm 451 \\
(B, C, E)\end{array}$ & $\begin{array}{l}25 \pm 8 \\
(A, D)\end{array}$ & $\begin{array}{l}85 \pm 14 \\
\text { (A) }\end{array}$ & $\begin{array}{c}0.79 \pm 0.26 \\
\text { (C) }\end{array}$ \\
\hline Illite (IMt-1) & $\begin{array}{c}12301 \pm 580 \\
(\mathrm{~A})\end{array}$ & $\begin{array}{l}9 \pm 4 \\
(\mathrm{~A}, \mathrm{~B})\end{array}$ & $\begin{array}{c}376 \pm 18 \\
(\mathrm{~A}, \mathrm{C})\end{array}$ & $\begin{array}{c}0.29 \pm 0.11 \\
\text { (A) }\end{array}$ \\
\hline Illite (IMt-2) & $\begin{array}{c}11712 \pm 3920 \\
\text { (A) }\end{array}$ & $\begin{array}{l}5 \pm 0 \\
(\mathrm{~B})\end{array}$ & $\begin{array}{l}418 \pm 140 \\
(\mathrm{~A}, \mathrm{D})\end{array}$ & $\begin{array}{c}0.19 \pm 0.01 \\
(\mathrm{~A})\end{array}$ \\
\hline Illite (Ward's) & $\begin{array}{c}9442 \pm 1840 \\
\text { (A) }\end{array}$ & $\begin{array}{c}6 \pm 2 \\
(\mathrm{~B})\end{array}$ & $\begin{array}{c}358 \pm 70 \\
(\mathrm{~A}, \mathrm{E})\end{array}$ & $\begin{array}{l}0.21 \pm 0.07 \\
\text { (A) }\end{array}$ \\
\hline Illite (I-API-35) & $\begin{array}{c}10760 \pm 2569 \\
(\mathrm{~A})\end{array}$ & $\begin{array}{c}12 \pm 1 \\
(\mathrm{~A})\end{array}$ & $\begin{array}{c}153 \pm 37 \\
\text { (A) }\end{array}$ & $\begin{array}{c}0.18 \pm 0.02 \\
\text { (A) }\end{array}$ \\
\hline Illite (I-API-Green) & $\begin{array}{c}7780 \pm 1485 \\
(\mathrm{~A}, \mathrm{~B})\end{array}$ & $\begin{array}{c}6 \pm 1 \\
(\mathrm{~B})\end{array}$ & $\begin{array}{c}289 \pm 55 \\
(\mathrm{~A}, \mathrm{~B})\end{array}$ & $\begin{array}{l}0.21 \pm 0.02 \\
\text { (A) }\end{array}$ \\
\hline Vermiculite (VId-1) & $\begin{array}{c}10868 \pm 5648 \\
\text { (A) }\end{array}$ & $\begin{array}{l}4 \pm 1 \\
(B)\end{array}$ & $\begin{array}{c}385 \pm 200 \\
(\mathrm{~A}, \mathrm{~F}, \mathrm{H})\end{array}$ & $\begin{array}{l}0.13 \pm 0.02 \\
\text { (A) }\end{array}$ \\
\hline Vermiculite (VTx-1) & $\begin{array}{l}309 \pm 38 \\
\text { (D) }\end{array}$ & $\begin{array}{l}60 \pm 5 \\
(C, D)\end{array}$ & $\begin{array}{c}8 \pm 1 \\
(G)\end{array}$ & $\begin{array}{c}1.52 \pm 0.12 \\
(B, C)\end{array}$ \\
\hline Mica (Muscovite) & $\begin{array}{c}5729 \pm 4364 \\
(\mathrm{~A}, \mathrm{E})\end{array}$ & $\begin{array}{c}30 \pm 2 \\
\text { (B) }\end{array}$ & $\begin{array}{c}637 \pm 485 \\
(\mathrm{~B}, \mathrm{E}, \mathrm{H})\end{array}$ & $\begin{array}{c}3.36 \pm 0.17 \\
\text { (B) }\end{array}$ \\
\hline Mica (Biotite) & $\begin{array}{c}6556 \pm 3829 \\
(\mathrm{~A}, \mathrm{C})\end{array}$ & $\begin{array}{c}10 \pm 5 \\
\text { (A) }\end{array}$ & $\begin{array}{c}1285 \pm 751 \\
(\mathrm{C}, \mathrm{D}, \mathrm{E}, \mathrm{F})\end{array}$ & $\begin{array}{c}2.61 \pm 0.93 \\
\text { (B) }\end{array}$ \\
\hline
\end{tabular}

(a) Means within a column followed by the same capital letter are not significantly different at the $5 \%$ level of probability according to Bonferroni's multiple comparison method (Neter and Wasserman, 1974).

Experiment \#2: Desorption of ${ }^{137} \mathrm{Cs}$

Most of the ${ }^{137} \mathrm{Cs}$ desorbed from the kaolinite, montmorillonite, and muscovite minerals when they were put in contact with $0.1 \mathrm{M} \mathrm{NH}_{4} \mathrm{Cl}$ solution (Tables 4 and 5). This result was expected for the kaolinite and montmorillonite due to the non-specific binding mechanism of cesium to these minerals. However, both micas had unexpectedly high desorption values. The cause for this is not known.

The percent $\mathrm{Cs}$ desorbed from all the treated samples was less than that for the nontreated samples (Table 6). This suggests that carbonate, organic, and/or Fe-oxide coatings may be weaker sorbing constituents than the underlying mineral phases. These coatings would be expected to form weaker bonds with Cs than the micas or illites. The high desorption value may, in part, be attributed to Cs sorbing to surface coatings. Overall, the nontreated minerals with the highest sorption and the lowest desorption values were the VId-1 vermiculite, and the IMt-1 and Ward's illites. An important aside is that these results suggest that the $0.1 \mathrm{M} \mathrm{NH}_{4} \mathrm{Cl}$ did not cause the interlayers to collapse. 
WSRC-TR-99-00229, Rev. 0

June 3, 1999

Table 6. Difference in Kd and Percent Desorption Values of Cs-137 Between Nontreated and Treated Samples

\begin{tabular}{lcc}
\hline Mineral & $\begin{array}{c}\text { \%-Desorbed } \\
\text { nontreated } \\
\text { (\% difference) }\end{array}$ & $\begin{array}{c}\mathrm{Kd}_{\text {nontreated }}-\mathrm{Kd}_{\text {reated }} \\
\text { (mL/g difference) }\end{array}$ \\
\hline Kaolinite (KGa-2) & 11 & -97 \\
Na-Mont. (SWy-2) & 65 & -1994 \\
Illite (IMt-1) & 11 & 48613 \\
Illite (IMt-2) & 19 & -984 \\
Illite (Wards) & 15 & 19655 \\
Illite (I-API-35) & 39 & -1436 \\
Illite (I-API-Green) & 26 & 13062 \\
Vermiculite (VId-1) & 1 & 11091 \\
Vermiculite (VTx-1) & 9 & 314 \\
Mica (Muscovite) & 86 & -3751 \\
Mica (Biotite) & 40 & 6909 \\
\hline
\end{tabular}

It was anticipated that a ranking of the minerals by the $\%$ desorption values would be: illite $<$ mica $<$ vermiculite $<<$ montmorillonite $<<$ kaolinite. Cesium was expected to desorb the least from the illites because they have more exposed Cs-specific sorption sites (ditrigonal sites) from frayed-edge sites (Figure 1), than mica. Vermiculite interlayers tend to expand, permitting greater access for the competing $\mathrm{NH}_{4}^{+}$ ions to displace Cs. Montmorillonite has too weak a surface charge to pull the Cs into the ditrigonal opening in the tetrahedral sheet. Additionally, montmorillonite charge originates in the octahedral layer, which may be too far from the surface sorption site to pull the Cs into the ditrigonal opening. Finally, kaolinite has little charge and no site-specific Cs binding sites, thus little electrostatic or specific sorption was anticipated.

An expected trend that was not observed was biotite having a greater percentage of Cs desorbed from its surface than muscovite (Fanning et al., 1989). When the dipoles of the octahedral hydroxyls of a mica crystal are perpendicular to the basal planes (as in trioctahedral micas such as biotite), their positive dipoles are slightly closer to cations in the interlayer space. The closer dipole increases the total repulsive force felt by the Cs ions and makes the Cs ions more likely to leave the mineral. The positive dipole of the octahedral hydroxyls in dioctahedral micas, such as muscovite, is oriented toward a nearby vacant octahedral position, therefore the distance between hydroxyl protons and interlayer $\mathrm{Cs}$ in dioctahedral micas is larger, the anionic field interacting with Cs is stronger, and Cs is held more tightly. This reasoning is usually invoked to explain why biotite releases $\mathrm{K}$, an analogue to $\mathrm{Cs}$, faster than muscovite in soils, and why lower $\mathrm{K}$ activities in solution are required for the release of $\mathrm{K}$ from muscovite than from biotite.

\section{Experiment \#3. Proof of Concept using Pond B sediment}

Experiment \#3 was conducted to test whether or not incremental additions of the candidate minerals would reduce the mobility of ${ }^{137} \mathrm{Cs}$ contaminated, kaolinitic-dominated sediments from Pond B. Mineral selection for use in the proof-of-concept experiment was based on the results from Experiments \#1 and \#2. Overrall, IMt-1 and VId-1, had the highest $\mathrm{K}_{d}$ values and lowest desorption values. These mineral 
treatments lowered the activity released into the aqueous phase (Figure 4). The total activity released decreased with increasing amounts of mineral amendment (Figure 4). Statistical analyses indicated that the differences between the Pond B controls (Sed-cntrl) and the treatments containing $1 \mathrm{~g}$ of mineral were marginally significant for both VId-1 $(\mathrm{P}=0.054)$ and IMt-1 $(\mathrm{P}=0.08)$. With only two replicates per treatment, these results are very promising. These data suggest that applying mineral amendments to SRS contaminated sediments could reduce ${ }^{137} \mathrm{Cs}$ bioavailability. We believe more replicates would have reduced the variation among treatments and improved the statistical rigor of our tests.

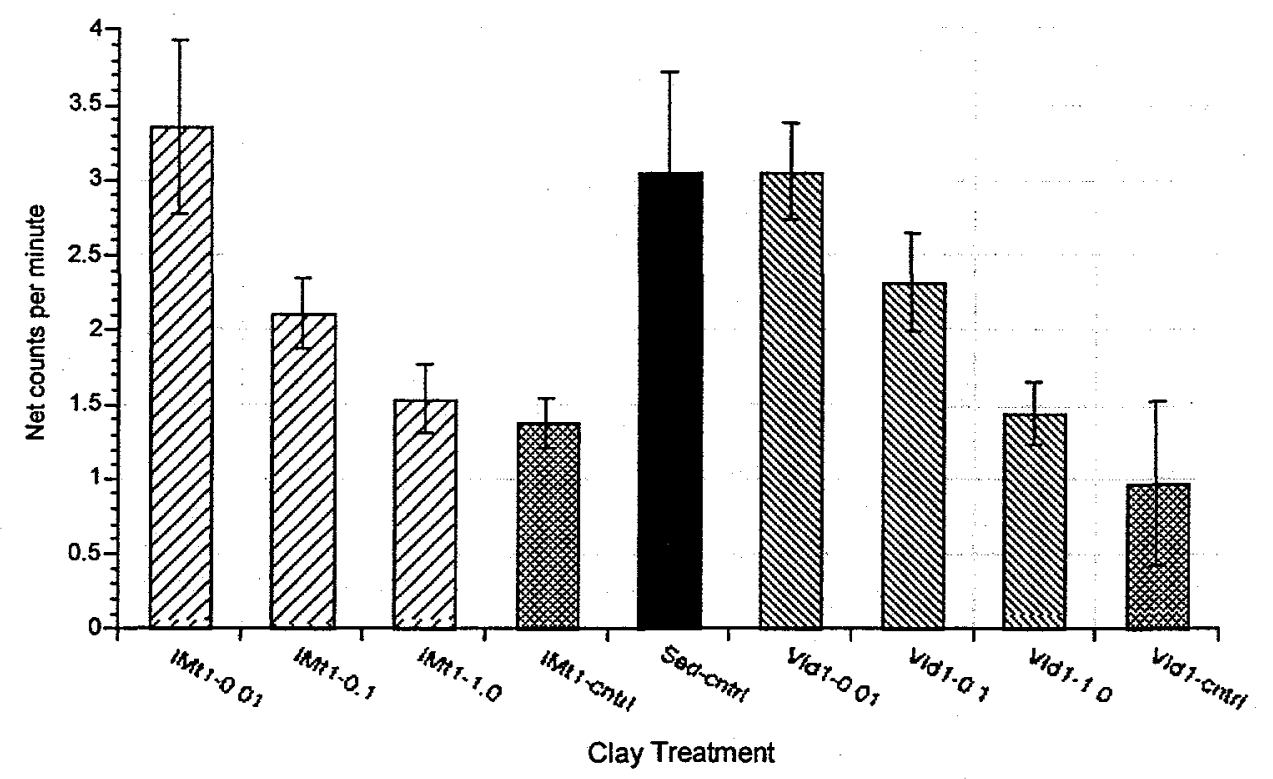

Figure 4. Results from proof-of-concept experiment. Data show the reduction in total activity obtained when incremental increases $(0.01,0.1$ and $1.0 \mathrm{~g})$ of illite (IMt1) and vermiculite (VId1) amendments were added to Pond B sediments. Columns followed by the same letter were not significantly at the $5 \%$ level.

\section{$X$-ray Fluorescence (XRF) Analysis}

$\mathrm{X}$-ray fluorescence (XRF) analysis of the nontreated minerals provided information about the bulk chemistry ( $\mathrm{K}, \mathrm{Ca}, \mathrm{Ti}, \mathrm{Cr}, \mathrm{Fe}, \mathrm{Zn}, \mathrm{As}, \mathrm{Sr}, \mathrm{Zr}, \mathrm{Sb}, \mathrm{Ba}, \mathrm{Ag}, \mathrm{U}$, and $\mathrm{Th}$ ) of the specimens. XRF data are provided in Appendix B. XRF analyses were not conducted on treated samples because it was not known what artifacts these treatments would introduce into the analyses. Additionally, these coatings account for a small percentage of the mass of these particular minerals, likely less than $3 \%$. Thus, it is anticipated that the elemental composition would be quite similar for both treated and nontreated samples. Two possible exceptions would be $\mathrm{Fe}$, which would concentrate on the surface as oxyhydroxyl coatings, and $\mathrm{Ca}$, which would be concentrated on the surface as a result of cation exchange and as part of carbonate coatings. Thus, XRF analysis of nontreated sediments may overestimate the amount of $\mathrm{Fe}$ and $\mathrm{Ca}$ on treated minerals. 
Potassium, when converted to $\mathrm{K}_{2} \mathrm{O}$ can be used as a rough approximation of the total amount micaceous material present in a sample. Fanning et al. (1989) reported that muscovite, biotite, and illite generally consists of $11.8,10.5$ and $7 \% \mathrm{~K}_{2} \mathrm{O}$, respectively. Whereas, vermiculite, smectite, and kaolinite is expected to have essentially no $\mathrm{K}_{2} \mathrm{O}$. The $\mathrm{K}_{2} \mathrm{O}$ concentrations reported in Table 7 are nearly identical to those reported by Fanning et al. (1989); muscovite, biotite, and the average illite consisted of 11.1, 10.1, and $6.8 \% \mathrm{~K}_{2} \mathrm{O}$, respectively; kaolinite and smectite had negligible concentrations of $\mathrm{K}_{2} \mathrm{O}$. One notable disparity between expected and measured $\mathrm{K}_{2} \mathrm{O}$ concentration was with VId-1 vermiculite, which contained $5 \% \mathrm{~K}_{2} \mathrm{O}$ (essentially no $\mathrm{K}_{2} \mathrm{O}$ was expected). This is a staggeringly high amount of $\mathrm{K}_{2} \mathrm{O}$ for a vermiculite. As explained in association with Figure 1, part of the definition of a vermiculite is that $\mathrm{K}$ is replaced as a interlayer cation with hydrated cations, such as $\mathrm{Ca}$ and $\mathrm{Mg}$. The high sorption and low desorption values (Tables 4 and 5), along with the high $\mathrm{K}_{2} \mathrm{O}$ concentrations strongly suggests that some micaceous or illitic material exists in VId-1. In fact, the $\mathrm{K}_{2} \mathrm{O}$ data suggests that there is almost certainly more micaceous or illitic material in the sample than vermiculite. X-ray diffraction analysis could provide definitive proof as to whether illites and micas are in this sample.

Correlation coefficients were calculated between the elemental composition of the minerals, and $\mathrm{K}_{\mathrm{d}}$ and desorption values (Tables 8 and 9). In general, the treated and nontreated minerals had similar correlations. The correlation with the treated minerals were slightly greater than with the nontreated minerals, which is likely attributed to the fact that the treatments removed coatings that masked the effects of the minerals. As mentioned above, the XRF results largely reflect the elemental composition of the underlying minerals. From Table 9 it can be seen that $K$ was positively correlated to $K_{d}$ and $K_{d-s u r f}$ values and negative correlated to desorption values. This is consistent with the notion that $K$ is an indirect indicator of the amount of micaceous and illitic material in the solid phase. An important application of this information is that XRF data, which can be easily obtained with a portable field unit, may be valuable for evaluating the propensity of a sediment to sorb and retain Cs. 
WSRC-TR-99-00229, Rev. 0 June 3, 1999

Table 7. Selected Elemental Concentrations $(\mathrm{mg} / \mathrm{kg})$ of Nontreated Minerals by X-ray Fluorescence Analysis

\begin{tabular}{lccccc}
\hline Mineral & $\mathrm{K}\left(\% \mathrm{~K}_{2} 0\right)$ & $\mathrm{Ca}$ & $\mathrm{Ti}$ & $\mathrm{Fe}$ & $\mathrm{Rb}$ \\
\hline Kaolinite (KGa-2) & $534(0.1)$ & 811 & 11,527 & 6706 & $\mathrm{BDL}^{(\mathrm{a})}$ \\
Na-Mont. (SWy-2) & $5781(0.7)$ & 10,640 & 621 & 21,887 & $\mathrm{BDL}$ \\
Illite (IMt-1) & $69,604(8.4)$ & 10,209 & 4017 & 41,601 & 309 \\
Illite (IMt-2) & $67,423(8.1)$ & 4037 & 3728 & 38,108 & 218 \\
Illite (Wards) & $48,070(5.8)$ & 7868 & 4321 & 33,521 & 196 \\
Illite (I-API-35) & $42,818(5.2)$ & 3518 & 4404 & 39,346 & 197 \\
Illite (I-API-Green) & $54,668(6.6)$ & 9712 & 4605 & 29,978 & 218 \\
Vermiculite (VId-1) & $42,375(5.1)$ & 16,413 & 236 & 33,337 & 272 \\
Vermiculite (VTx-1) & $519(0.1)$ & 118,451 & $\mathrm{BDL}$ & 6,186 & $\mathrm{BDL}$ \\
Mica (Muscovite) & $92,501(11.1)$ & 1370 & 910 & 13,476 & 1599 \\
Mica (Biotite) & $83,723(10.1)$ & 16,581 & 12,120 & 80,203 & 907
\end{tabular}

(a) $\mathrm{BDL}=$ below detection limits

Table 8. Correlation Coefficient Values Between Mineral Elemental Concentrations and Sorption/Desorption Values of Nontreated Minerals

\begin{tabular}{lcccccccc}
\hline & $\mathrm{K}$ & $\mathrm{Ca}$ & $\mathrm{Ti}$ & $\mathrm{Fe}$ & $\mathrm{Rb}$ & $\begin{array}{c}\mathrm{K}_{\mathrm{d}} \\
(\mathrm{mL} / \mathrm{g})\end{array}$ & $\begin{array}{c}\text { Desorbed } \\
(\%)\end{array}$ & $\begin{array}{c}\mathrm{K}_{\mathrm{d}-\text { surface }} \\
\left(\mathrm{mL} / \mathrm{m}^{2}\right)\end{array}$ \\
\hline $\mathrm{Ca}$ & -0.44 & & & & & & & \\
$\mathrm{Ti}$ & -0.05 & -0.02 & & & & & & \\
$\mathrm{Fe}$ & $0.60^{(\mathrm{a})}$ & -0.30 & 0.37 & & & & & \\
$\mathrm{Rb}$ & $0.84^{(\mathrm{a})}$ & -0.20 & 0.04 & -0.09 & & & & \\
$\mathrm{Kd}(\mathrm{mL} / \mathrm{g})$ & 0.40 & -0.21 & -0.10 & 0.39 & -0.43 & & & \\
Desorbed $(\%)$ & -0.29 & 0.03 & 0.21 & -0.51 & $0.89^{(\mathrm{a})}$ & $-0.68^{(\mathrm{a})}$ & & \\
$\mathrm{K}_{\mathrm{d} \text {-surface }}\left(\mathrm{mL} / \mathrm{m}^{2}\right)$ & $0.59^{(\mathrm{a})}$ & -0.17 & 0.42 & $0.85^{(\mathrm{a})}$ & 0.05 & $0.63^{(\mathrm{a})}$ & -0.46 & \\
$\begin{array}{l}\text { Desorption } \\
\text { (\%) }\end{array}$ & 0.35 & -0.17 & 0.38 & 0.05 & $0.96^{(\mathrm{a})}$ & -0.41 & $0.71^{(\mathrm{a})}$ & 0.14 \\
\hline
\end{tabular}

(a) Significant at $\leq 5 \%$ level of significance. The critical correlation coefficient for 10 degrees of freedom at $\mathrm{P}<0.05$ is 0.58 ; at $\mathrm{P}<0.01$ is 0.71 .

Iron can exist either as coatings or in the mineral structure. Iron exists in the structure of many 2:1 minerals. It is one of the dominant divalent cations in the octahedral sheet of many illites and biotite (ideal formulae are presented in Table 1). The Fe concentration values in Table 7 are consistent with reported values (Dixon and Weed 1989). Iron concentrations were inversely correlated to desorption values and directly correlated to $\mathrm{K}_{\mathrm{d} \text {-surf }}$ (Table 9 ). This may in part be attributed to the fact that Fe-oxides have a large propensity to sorb Cs via surface complexation (a bond between surface hydroxides and Cs), and this bond is weaker than that of the ditrigonal sites on illites and micas. However, there was not a significant ( $P$ $<0.05$ ) correlation between $\mathrm{Fe}$ and difference in \% desorption or difference in $\mathrm{K}_{d}$ values of nontreated and treated samples (Table 6). Given the multiple locations that $\mathrm{Fe}$ can exist in these varying mineral 
assemblages, it is not surprising that significant correlations did not occur. At most, this suggests that in general the role of $\mathrm{Fe}$ as a coating or as an oxidized structural component did not affect sorption and desorption. Importantly, the treatments had dramatic effects on the sorption (IMt-1, Wards and I-APIGreen illites) and desorption (Na-montmorillonite and muscovite) of Cs-137 from selected minerals.

Table 9. Correlation Coefficient Values Between Mineral Elemental Concentrations and Sorption/Desorption Values of Treated Minerals ${ }^{(\mathbf{a})}$

\begin{tabular}{lcccccccc}
\hline & $\mathrm{K}$ & $\mathrm{Ca}$ & $\mathrm{Ti}$ & $\mathrm{Fe}$ & $\mathrm{Rb}$ & $\begin{array}{c}\mathrm{K}_{\mathrm{d}} \\
(\mathrm{mL} / \mathrm{g})\end{array}$ & $\begin{array}{c}\text { Desorbed } \\
(\%)\end{array}$ & $\begin{array}{c}\mathrm{K}_{\mathrm{d}-\text { surf }} \\
\left(\mathrm{mL} / \mathrm{m}^{2}\right)\end{array}$ \\
\hline $\mathrm{Ca}$ & -0.44 & & & & & & & \\
$\mathrm{Ti}$ & -0.05 & -0.02 & & & & & & \\
$\mathrm{Fe}$ & $0.60^{(\mathrm{b})}$ & -0.30 & 0.37 & & & & & \\
$\mathrm{Rb}$ & $0.84^{(\mathrm{b})}$ & -0.20 & 0.04 & -0.09 & & & & \\
$\mathrm{~K}_{\mathrm{d}}(\mathrm{mL} / \mathrm{g})$ & $0.64^{(\mathrm{b})}$ & -0.47 & -0.36 & 0.55 & $-0.77^{(\mathrm{b})}$ & & & \\
Desorption $(\%)$ & $-0.62^{(\mathrm{b})}$ & 0.29 & 0.50 & $-0.61^{(\mathrm{b})}$ & $0.92^{(\mathrm{b})}$ & $-0.82^{(\mathrm{b})}$ & & \\
$\mathrm{K}_{\mathrm{d} \text {-surf }}\left(\mathrm{mL} / \mathrm{m}^{2}\right)$ & $0.79^{(\mathrm{b})}$ & -0.25 & 0.34 & $0.80^{(\mathrm{b})}$ & $0.60^{(b)}$ & 0.29 & -0.42 & \\
Desorbed $\left(\% / \mathrm{m}^{2}\right)$ & -0.17 & -0.04 & $0.59^{(\mathfrak{b})}$ & -0.30 & $0.97^{(b)}$ & $-0.68^{(b)}$ & $0.84^{(b)}$ & 0.07 \\
\hline
\end{tabular}

(a) XRF elemental analyses were conducted using nontreated mineral samples. XRF analysis samples the entire mineral, not just the surface; thus the difference in the elemental composition as a result of removing the coatings would likely be minimal for all elements except $\mathrm{Ca}$ (the dominant exchangeable cation in this system) and $\mathrm{Fe}$ (the dominant element in oxyhydroxide coatings).

(b) Significant at $\leq 5 \%$ level of significance. The critical correlation coefficient for 10 degrees of freedom at $\mathrm{P}<0.05$ is 0.58 ; at $\mathrm{P}<0.01$ is 0.71 .

Rubidium is a monovalent alkaline cation that is slightly smaller than $\mathrm{Cs}^{+}$, but is larger than $\mathrm{K}^{+}$and $\mathrm{NH}_{4}{ }^{+}$. Rubidium concentrations were highly correlated to all four sorption/desorption parameters (Table 9). This has not been reported before. Especially difficult to explain is why mineral $\mathrm{Rb}$ concentrations are directly correlated to $\mathrm{K}_{\mathrm{d} \text {-surf }}$ and inversely correlated to the traditional $\mathrm{K}_{\mathrm{d}}$ construct. Given these exceptionally strong correlations, additional research needs to be conducted to explain this result.

\section{CONCLUSIONS}

Cesium-137 has contaminated a large area of the wetlands on the Savannah River Site. During the summer, when the hypolimnion become anoxic, about $1 \%$ of the ${ }^{137} \mathrm{Cs}$ that is bound to the sediments is released into the overlying water (Evans et al., 1983, Whicker et al. 1990). The cause for the release is likely the combined effect of increased $\mathrm{NH}_{4}{ }^{+}$concentrations and the dissolution of $\mathrm{Fe}$ (III)-oxides during anoxic conditions. Ammonium can displace ${ }^{137} \mathrm{Cs}$ from sorption sites on sediments, and $\mathrm{Fe}$ (III)-oxides can release sorbed $\mathrm{Cs}$ upon reduction to $\mathrm{Fe}(\mathrm{II})$. This annual release of $\mathrm{Cs}$ is appreciably more mobile and more accessible to the biosphere than that which is bound to the sediments. Although representing only a small percentage of the total inventory, the released ${ }^{137} \mathrm{Cs}$ is sufficient to cause measurable concentrations in all components of the wetlands (e.g. water, plants, aquatic insects, fish, etc.), and results in ${ }^{137} \mathrm{Cs}$ being the primary driver in human and ecological risks on the SRS (Whicker et al. 1993). Remediation of the contaminated wetlands is problematic because current techniques destroy the sensitive ecosystem and 
generate a higher dose to workers. To address the problem, we proposed a non-intrusive, in situ technology to sequester ${ }^{137} \mathrm{Cs}$ in sediments. The technology involves introducing illitic minerals to the surface of Cs-contaminated waters. Such minerals characteristically have a strong affinity for Cs, and once bound, tend to hold Cs tenaciously. These characteristics are opposite those of the predominant mineral on the SRS: kaolinite. The mineral amendments would capture ${ }^{137} \mathrm{Cs}$ during its annual summer release, thereby reducing transport to the biota and providing a non-intrusive remediation solution.

As an initial test of our hypothesis, three experiments were conducted. The first two quantified adsorptive and desorptive properties of eleven candidate mineral amendments. The intent was to identify specific minerals that could be used for the proposed technology. An important additional objective was to identify mineral specifications so that quarried minerals could be appropriately chosen if the technology is scaled-up to a field application. The third experiment was a proof-of-concept of the proposed technology, whereby we incrementally added candidate minerals to kaolinitic-dominated sediments of Pond B to see if mobility of ${ }^{137} \mathrm{Cs}$ was reduced.

The most important conclusions from the study of cesium adsorption and desorption were:

- Several clay minerals (IMt-1, IMt-2, Ward's, VId-1) were identified to have high Cs- $\mathrm{K}_{\mathrm{d}}$ values and low Cs-desorption values. Cs- $\mathrm{K}_{\mathrm{d}}$ values of $>10,000 \mathrm{~mL} \mathrm{~g}^{-1}$ and \% desorption of $<10 \%$ (under extremely harsh experimental conditions) can be expected from these minerals.

- Minerals treated to remove carbonates, free iron oxides, and organic coatings had consistently, and in some cases appreciably, less Cs desorption than untreated minerals.

- Specific mineral characteristics were identified and should be used when choosing quarried minerals for this technology. The quarried minerals should contain illite (not kaolinite, smectite, or biotite) with moderate levels of $\mathrm{K}_{2} \mathrm{O}$, and should contain low concentrations of surface coatings.

The most important conclusion from the proof-of-concept study was:

- Incremental additions of two clay minerals (IMt-1 and VId-1) to Pond B sediments, contaminated over 35 years ago, appreciably reduced desorption of ${ }^{137} \mathrm{Cs}$. The data revealed a trend of reduced total soluble activity with increasing amounts of mineral amendment.

One intention of this study was to provide information regarding a "go/no go" decision for future work. Since the proof-of-concept was successful and several minerals were identified as potential candidates for this technology, a "go" decision was made. Future work should address the following issues.

- Limnocorral Study: All the experiments to date have been bench-top, laboratory-scale applications. A replicated, mesocosm approach using lake limnocorrals is needed to quantify the ability of the mineral amendments to decrease ${ }^{137} \mathrm{Cs}$ mobility under natural conditions.

- Water Quality and Ecological Impact Study: Impact of the proposed technology on the environment needs to be quantified; including changes to water quality, and the biological effects of the mineral amendments on plants, aquatic insects, and fish populations. 
- Particle-size Study: Examine the influence of particle size on ${ }^{137} \mathrm{Cs}$ adsorption and desorption. If particle size is too small the mineral may be overly dispersive in the environment, if too large, the effective surface area for ${ }^{137} \mathrm{Cs}$ adsorption would be reduced.

- Cradle-to-Grave Cost Analysis of Technology: Consider the engineering aspects of applying mineral amendments and quantify the costs.

- Specifications for Quarried Minerals: Finally, additional characterization of the minerals would further help in identifying important specifications for the quarried minerals. X-ray analysis would identify and semi-quantify the various components of these mineral assemblages. Measurement of the concentration of frayed-edge sites (Cremers et al. 1988) would quantify the number of exchange sites that "irreversibly sorb" (e.g. ditrigonal sorption sites) versus reversibly sorb (e.g., cation exchange sites) ${ }^{137} \mathrm{Cs}$ on illites and micas.

\section{ACKNOWLEDGEMENTS}

Primary funding for this project was by Westinghouse Savannah River Company, contract \# 10-21RR267-098. Additional funding was provided by Financial Assistance Award Number DE-FC0996SR 18546 from the U.S. Department of Energy to the University of Georgia Research Foundation. The information contained in this article was developed during the course of work under Contract Number DEAC09-96SR18500 with the U.S. Department of Energy.

\section{LITERATURE CITED}

Ames, L. L., and D. Rai. 1978. Radionuclide interactions with rock and soil media. Volume 1. PB292460. Pacific Northwest National Laboratory, Richland, WA.

Bailey, S.W. 1984. Classification and structures of the micas. p. 1-12. In S.W. Bailey (ed.) Micas. Vol. 13, Reviews in Mineralogy. Mineralogical Soc. of Am., Washington, DC.

Carlton, H., L. R. Bauer, A. B. Evans, L. A. Beary, C. E. Murphy, Jr., J. E. Pinder, III and R. N. Strom. 1992. Cesium in the Savannah River Site Environment. WSRC-RP-92-250,Westinghouse Savannah River Co., Savannah River Laboratory, Aiken, SC.

Cremers, A., A. Elsen, P. De Preter and A. Maes. 1988. Quantitative analysis of radiocasesium retention in soils. Nature 335:247-249.

Dixon, J. B., and S. B. Weed. 1989. Minerals in Soil Environments. Second Edition. Soils Science Society of America. Madison, WI.

Evans, D. W., J. J. Alberts and R. A. Clark, III. 1983. Reversible ion-exchange fixation of cesium-137 leading to mobilization from reservoir sediments. Geochimicia et Cosmochimica Acta. 47:1041-1049.

Fanning, D.S., V.Z. Keramidas, and M.A. El-Desoky. 1989. Micas. p. 551-634. In J. B. Dixon and S. B. Weed (ed.) Minerals in soil environments. $2^{\text {nd }}$ ed. Soil Sci. Soc. Am. Book Ser. 1, Madison, WI.

Francis, C. W. and F. S. Brinkley. 1976. Preferential adsorption of 137 Cs to micaceous minerals in contaminated freshwater sediment. Nature 260:511-513.

Garten, C. T., Jr. and D. Paine. 1977. A multivariate analysis of factors affecting radiocesium uptake by Sagittaria latifolia in coastal plain environments. J. Environ. Qual. 6:78-82. 
Hinton, T. G., C. M. Bell, F. W. Whicker and T. Philippi. 1999. Parameters influencing ${ }^{137}$ Cs uptake by vegetation colonizing a contaminated lake bed over a three-year period. J. Environ. Rad.:44:1-19.

Kunze, G. W., and J. B. Dixon. 1986. Pretreatment for Mineralogical Analysis. In: A. Klute (Ed.), Methods of Soil Analysis, Part 1, Physical and Mineralogical Methods, Second Edition. American Society of Agronomy, Inc. Publisher, Madison, WI.

Neter, J., and W. Wasserman. 1974. Applied Linear Statistical Models. Richard D. Irwin, Inc. Homewood, IL.

Pinder, J. E., III, C. T. Garten, Jr., and D. Paine. 1980. Factors affecting radiocesium uptake by plants inhabiting a contaminated floodplain. Acta Oecologica. 1:3-10.

Ruhe, R. V., and E. A. Matney. 1980. Clay Mineralogy of Selected Sediments and Soils at the Savannah River Plant, Aiken, South Carolina. DP-MS-80-119. Westinhouse Savannah River Company. Aiken, SC.

Staunton, S., and M. Roubaud. 1997. Adsorption of 137-Cs on montmorillonite and illite: Effect of Charge Compensating cation, ionic strength concentration of $\mathrm{Cs}, \mathrm{K}$, and fulvic acid. Clays Clay Miner. 45:251-260.

Seel, J. F., F. W. Whicker and D. C. Adriano. 1995. Uptake of ${ }^{137} \mathrm{Cs}$ in vegetable crops grown on a contaminated lakebed. Health Phys. 68:793-799.

Tamura, T. 1972. Sorption phenomena significant in radioactive waste disposal. Am. Assoc. Pet. Geol. Mem. 18:318-333.

Whicker, F. W. and V. Schultz. 1982. Radioecology: Nuclear Energy and the Environment. CRC Press, Inc. Boca Raton, FL.

Whicker, F. W., J. E. Pinder, III, J. W. Bowling, J. J. Alberts and I. L. Brisbin, Jr. 1990. Distribution of long-lived radionuclides in an abandoned reactor cooling reservoir. Ecolog. Mon., 60:471-496.

Whicker, F. W., T. G. Hinton, D. J. Niquette and J. Seel. 1993. Health risks to hypothetical residents of a radioactively contaminated lake bed. IN: ER'93: Environmental Remediation Conference. Oct 24-28, 1993. Augusta, Ga. 


\section{APPENDICES}

Appendix A. $K_{d}$ and \% Desorption Values For Treated and Non-treated Minerals.

\begin{tabular}{|c|c|c|c|c|c|c|c|}
\hline Mineral & $\begin{array}{l}\text { Treated } \\
\text { (yes } / \text { no) }\end{array}$ & $\begin{array}{c}\mathrm{K}_{\mathrm{d}} \\
(\mathrm{mL} / \mathrm{g})\end{array}$ & $\begin{array}{c}\text { Mean } \\
\mathrm{K}_{\mathrm{d}} \\
(\mathrm{mL} / \mathrm{g})\end{array}$ & $\begin{array}{c}\text { Std. Dev. } \\
\mathrm{K}_{\mathrm{d}} \\
(\mathrm{mL} / \mathrm{g})\end{array}$ & $\begin{array}{c}\text { Desorbed } \\
(\%)\end{array}$ & $\begin{array}{c}\text { Mean } \\
\text { Desorbed } \\
(\%)\end{array}$ & $\begin{array}{c}\text { Std. Dev. } \\
\text { Desorbed } \\
(\%)\end{array}$ \\
\hline Illite (IMt-1) & Yes & 12948 & 12301 & 580 & 10.6 & 9.4 & 3.7 \\
\hline Illite (IMt-1) & Yes & 12124 & & & 12.3 & & \\
\hline Illite (IMt-1) & Yes & 11829 & & & 5.2 & & \\
\hline Illite (IMt-2) & Yes & 9382 & 11712 & 3920 & 5.6 & 5.2 & 0.4 \\
\hline Illite (IMt-2) & Yes & 9517 & & & 4.9 & & \\
\hline Illite (TMt-2) & Yes & 16238 & & & 5.2 & & \\
\hline Illite (Ward's) & Yes & 7695 & 9442 & 1840 & 3.9 & 5.6 & 1.7 \\
\hline Illite (Ward's) & Yes & 11363 & & & 5.7 & & \\
\hline Illite (Ward's) & Yes & 9267. & & & 7.4 & & \\
\hline Illite (I-API-35) & Yes & 12392 & 10760 & 2569 & 11.3 & 12.3 & 1.1 \\
\hline Illite (I-API-35) & Yes & 12088 & & & 12.2 & & \\
\hline Illite (I-API-35) & Yes & 7799 & & & 13.5 & & \\
\hline Illite (I-API-Green) & Yes & 6693 & 7780 & 1485 & 5.6 & 5.6 & 0.5 \\
\hline Illite (I-API-Green) & Yes & 7174 & & & 6.1 & & \\
\hline Illite (I-API-Green) & Yes & 9472 & & & 5.1 & & \\
\hline Na. Mont. (SWy-2) & Yes & 2545 & 2722 & 451 & 17.2 & 25.3 & 8.2 \\
\hline Na. Mont. (SWy-2) & Yes & 2386 & & & 33.6 & & \\
\hline Na. Mont. (SWy-2) & Yes & 3235 & & & 25.1 & & \\
\hline Kaolinite (KGa-2) & Yes & 497 & 335 & 141 & 73.2 & 105.6 & 28.7 \\
\hline Kaolinite (KGa-2) & Yes & 253 & & & 127.6 & & \\
\hline Kaolinite (KGa-2) & Yes & 255 & & & 116.1 & & \\
\hline Vermiculite (VId-1) & Yes & 4972 & 10868 & 5648 & 3.5 & 3.6 & 0.5 \\
\hline Vermiculite (VId-1) & Yes & 11404 & & & 3.2 & & \\
\hline Vermiculite (VId-1) & Yes & 16229 & & & 4.2 & & \\
\hline Vermiculite (VTx-1) & Yes & 268 & 309 & 38 & 63.6 & 60.2 & 4.9 \\
\hline Vermiculite (VTx-1) & Yes & 315 & & & 62.4 & & \\
\hline Vermiculite (VTx-1) & Yes & 343 & & & 54.6 & & \\
\hline Mica (Muscovite) & Yes & 4221 & 5729 & 4364 & 31.9 & 30.3 & 1.5 \\
\hline Mica (Muscovite) & Yes & 10647 & & & 28.9 & & \\
\hline Mica (Muscovite) & Yes & 2319 & & & 29.9 & & \\
\hline Mica (Biotite) & Yes & 4987 & 6556 & 3829 & 18.6 & 13.3 & 4.7 \\
\hline Mica (Biotite) & Yes & 10919 & & & 9.4 & & \\
\hline Mica (Biotite) & Yes & 3760 & & & 11.9 & & \\
\hline Illite (IMt-1) & No & 58837 & 60914 & 11554 & 20.1 & 20.6 & 1.4 \\
\hline Illite (IMt-1) & No & 73366 & & & 19.4 & & \\
\hline Illite (IMt-1) & No & 50539 & & & 22.2 & & \\
\hline Illite (IMt-2) & No & 12745 & 10728 & 3340 & 19.6 & 24.0 & 5.7 \\
\hline Illite (IMt-2) & No & 6873 & & & 30.4 & & \\
\hline Illite (IMt-2) & No & 12566 & & & 21.9 & & \\
\hline
\end{tabular}


WSRC-TR-99-00229, Rev. 0 June 3, 1999

Appendix A (Continued)

\begin{tabular}{|c|c|c|c|c|c|c|c|}
\hline Mineral & $\begin{array}{l}\text { Treated } \\
\text { (yes/no) }\end{array}$ & $\begin{array}{c}\mathrm{K}_{\mathrm{d}} \\
(\mathrm{mL} / \mathrm{g})\end{array}$ & $\begin{array}{c}\text { Mean } \\
\mathrm{K}_{\mathrm{d}} \\
(\mathrm{mL} / \mathrm{g})\end{array}$ & $\begin{array}{c}\text { Std. Dev. } \\
K_{d} \\
(\mathrm{~mL} / \mathrm{g})\end{array}$ & $\begin{array}{c}\text { Desorbed } \\
(\%)\end{array}$ & $\begin{array}{c}\text { Mean } \\
\text { Desorbed } \\
(\%)\end{array}$ & $\begin{array}{c}\text { Std. Dev. } \\
\text { Desorbed } \\
(\%)\end{array}$ \\
\hline Illite (Ward's) & No & 41181 & 29097 & 10515 & 19.9 & 20.4 & 3.5 \\
\hline Illite (Ward's) & No & 22031 & & & 24.1 & & \\
\hline Illite (Ward's) & No & 24080 & & & 17.1 & & \\
\hline Illite (I-API-35) & No & 10318 & 9323 & 1035 & 52.7 & 51.0 & 7.4 \\
\hline Illite (I-API-35) & No & 9399 & & & 43.0 & & \\
\hline Illite (I-API-35) & No & 8252 & & & 57.4 & & \\
\hline Illite (I-API-Green) & No & 22548 & 20841 & 2449 & 30.2 & 31.7 & 3.0 \\
\hline Illite (I-API-Green) & No & 21940 & & & 29.8 & & \\
\hline Illite (I-API-Green) & No & 18035 & & & 35.1 & & \\
\hline Na. Mont. (SWy-2) & No & 690 & 728 & 66 & 95.6 & 89.8 & 8.8 \\
\hline Na. Mont. (SWy-2) & No & 804 & & & 79.8 & & \\
\hline Na. Mont. (SWy-2) & No & 690 & & & 94.1 & & \\
\hline Kaolinite (KGa-2) & No & 233 & 238 & 7 & 156.2 & 117.2 & 54.6 \\
\hline Kaolinite (KGa-2) & No & 245 & & & 54.8 & & \\
\hline Kaolinite (KGa-2) & No & 234 & & & 140.6 & & \\
\hline Vermiculite (VId-1) & No & 32707 & 21959 & 10691 & 4.7 & 4.3 & 0.4 \\
\hline Vermiculite (VId-1) & No & 11326 & & & 3.9 & & \\
\hline Vermiculite (VId-1) & No & 21844 & & & 4.3 & & \\
\hline Vermiculite (VTx-1) & No & 658 & 623 & 47 & 60.9 & 69.1 & 10.9 \\
\hline Vermiculite (VTx-1) & No & 571 & & & 81.5 & & \\
\hline Vermiculite (VTx-1) & No & 641 & & & 64.9 & & \\
\hline Mica (Muscovite) & No & 1626 & 1978 & 320 & 126.5 & 116.4 & 11.2 \\
\hline Mica (Muscovite) & No & 2251 & & & 104.3 & & \\
\hline Mica (Muscovite) & No & 2057 & & & 118.4 & & \\
\hline Mica (Biotite) & No & 9647 & 13464 & 8362 & 49.1 & 53.1 & 3.5 \\
\hline Mica (Biotite) & No & 23054 & & & 54.9 & & \\
\hline Mica (Biotite) & No & 7692 & & & 55.3 & & \\
\hline
\end{tabular}


WSRC-TR-99-00229, Rev. 0 June 3, 1999

Appendix B. XRF Elemental Analysis (All Values Not Presented Are Below Detection Limit).

\begin{tabular}{|c|c|c|}
\hline \multicolumn{3}{|c|}{ Illite (IMt-1) } \\
\hline Element & $\begin{array}{c}\text { Concentration } \\
(\mathrm{mg} / \mathrm{kg})\end{array}$ & $\begin{array}{l}\text { Std. Dev. } \\
(\mathrm{mg} / \mathrm{kg})\end{array}$ \\
\hline $\mathrm{CrHI}$ & 166 & 106 \\
\hline $\mathrm{K}$ & 69605 & 379 \\
\hline $\mathrm{Ca}$ & 10209 & 143 \\
\hline $\mathrm{Ti}$ & 4017 & 82 \\
\hline $\mathrm{CrLO}$ & 198 & 53 \\
\hline $\mathrm{Fe}$ & 41601 & 372 \\
\hline $\mathrm{Ni}$ & 135 & 38 \\
\hline $\mathrm{Zn}$ & 92 & 15 \\
\hline As & 18 & 11 \\
\hline $\mathrm{Sr}$ & 225 & 6 \\
\hline $\mathrm{Zr}$ & 99 & 3 \\
\hline $\mathrm{Rb}$ & 309 & 10 \\
\hline $\mathrm{Ba}$ & 359 & 8 \\
\hline $\mathrm{Ag}$ & 20 & 18 \\
\hline $\mathrm{U}$ & 15 & 6 \\
\hline Th & 15 & 3 \\
\hline
\end{tabular}

\section{Vermiculite (VId-1)}

\begin{tabular}{lcc}
\hline Element & $\begin{array}{c}\text { Concentration } \\
(\mathrm{mg} / \mathrm{kg})\end{array}$ & $\begin{array}{c}\text { Std. Dev. } \\
(\mathrm{mg} / \mathrm{kg})\end{array}$ \\
\hline $\mathrm{K}$ & 42375 & 299 \\
$\mathrm{Ca}$ & 16413 & 149 \\
$\mathrm{Ti}$ & 236 & 40 \\
$\mathrm{CrLO}$ & 321 & 44 \\
$\mathrm{Mn}$ & 3872 & 187 \\
$\mathrm{Fe}$ & 33337 & 320 \\
$\mathrm{Cu}$ & 61 & 18 \\
$\mathrm{Zn}$ & 974 & 30 \\
$\mathrm{As}$ & 24 & 10 \\
$\mathrm{Rb}$ & 272 & 9 \\
$\mathrm{Ba}$ & 304 & 7 \\
$\mathrm{U}$ & 7 & 5 \\
\hline
\end{tabular}


Appendix B (Continued)

\section{Illite (IMt-2)}

\begin{tabular}{lcc}
\hline Element & $\begin{array}{c}\text { Concentration } \\
(\mathrm{mg} / \mathrm{kg})\end{array}$ & $\begin{array}{c}\text { Std. Dev. } \\
(\mathrm{mg} / \mathrm{kg})\end{array}$ \\
\hline $\mathrm{CrHI}$ & 138 & 102 \\
$\mathrm{~K}$ & 67423 & 374 \\
$\mathrm{Ca}$ & 4037 & 115 \\
$\mathrm{Ti}$ & 3728 & 79 \\
$\mathrm{CrLO}$ & 145 & 52 \\
$\mathrm{Fe}$ & 38108 & 352 \\
$\mathrm{Co}$ & 207 & 119 \\
$\mathrm{Zn}$ & 88 & 15 \\
$\mathrm{As}$ & 30 & 11 \\
$\mathrm{Sr}$ & 135 & 5 \\
$\mathrm{Zr}$ & 126 & 3 \\
$\mathrm{Mo}$ & 5 & 3 \\
$\mathrm{Rb}$ & 218 & 9 \\
$\mathrm{Cd}$ & 88 & 26 \\
$\mathrm{Sn}$ & 37 & 16 \\
$\mathrm{Ba}$ & 187 & 6 \\
$\mathrm{Ag}$ & 59 & 17 \\
$\mathrm{U}$ & 16 & 5 \\
$\mathrm{Th}$ & 25 & 3 \\
\hline & &
\end{tabular}

\section{Mica (Muscovite)}

\begin{tabular}{lcc}
\hline Element & $\begin{array}{c}\text { Concentration } \\
(\mathrm{mg} / \mathrm{kg})\end{array}$ & $\begin{array}{c}\text { Std. Dev. } \\
(\mathrm{mg} / \mathrm{kg})\end{array}$ \\
\hline $\mathrm{K}$ & 92501 & 436 \\
$\mathrm{Ca}$ & 1370 & 121 \\
$\mathrm{Ti}$ & 910 & 42 \\
$\mathrm{CrLO}$ & 366 & 45 \\
$\mathrm{Fe}$ & 13476 & 213 \\
$\mathrm{Cu}$ & 47 & 17 \\
$\mathrm{Zn}$ & 152 & 15 \\
$\mathrm{As}$ & 199 & 12 \\
$\mathrm{Sr}$ & 3 & 2 \\
$\mathrm{Rb}$ & 1599 & 21 \\
$\mathrm{Cd}$ & 26 & 19 \\
$\mathrm{Sn}$ & 179 & 14 \\
$\mathrm{U}$ & 204 & 13 \\
$\mathrm{Th}$ & 106 & 6 \\
\hline
\end{tabular}


WSRC-TR-99-00229, Rev. 0 June 3, 1999

Appendix B (Continued)

Na-Montmorillonite

\begin{tabular}{lcc}
\hline Element & $\begin{array}{c}\text { Concentration } \\
(\mathrm{mg} / \mathrm{kg})\end{array}$ & $\begin{array}{c}\text { Std. Dev. } \\
(\mathrm{mg} / \mathrm{kg})\end{array}$ \\
\hline $\mathrm{K}$ & 5781 & 126 \\
$\mathrm{Ca}$ & 10640 & 105 \\
$\mathrm{Ti}$ & 621 & 37 \\
$\mathrm{CrLO}$ & 158 & 38 \\
$\mathrm{Fe}$ & 21887 & 241 \\
$\mathrm{Zn}$ & 135 & 14 \\
$\mathrm{As}$ & 46 & 10 \\
$\mathrm{Sr}$ & 310 & 6 \\
$\mathrm{Zr}$ & 172 & 3 \\
$\mathrm{Sb}$ & 8 & 7 \\
$\mathrm{Ba}$ & 79 & 4 \\
$\mathrm{Ag}$ & 19 & 13 \\
$\mathrm{U}$ & 58 & 5 \\
$\mathrm{Th}$ & 82 & 4
\end{tabular}

Illite (Ward's)

\begin{tabular}{lcc}
\hline Element & $\begin{array}{c}\text { Concentration } \\
(\mathrm{mg} / \mathrm{kg})\end{array}$ & $\begin{array}{c}\text { Std. Dev. } \\
(\mathrm{mg} / \mathrm{kg})\end{array}$ \\
\hline $\mathrm{CrHI}$ & 103 & 97 \\
$\mathrm{~K}$ & 48070 & 317 \\
$\mathrm{Ca}$ & 7868 & 120 \\
$\mathrm{Ti}$ & 4321 & 83 \\
$\mathrm{Fe}$ & 33521 & 322 \\
$\mathrm{Zn}$ & 126 & 15 \\
$\mathrm{As}$ & 47 & 11 \\
$\mathrm{Sr}$ & 75 & 4 \\
$\mathrm{Zr}$ & 157 & 3 \\
$\mathrm{Rb}$ & 196 & 8 \\
$\mathrm{Sb}$ & 16 & 9 \\
$\mathrm{Ba}$ & 207 & 6 \\
$\mathrm{Ag}$ & 40 & 16 \\
$\mathrm{U}$ & 26 & 5 \\
$\mathrm{Th}$ & 21 & 3 \\
\hline
\end{tabular}

Mica (Biotite)

\begin{tabular}{lcc}
\hline Element & $\begin{array}{c}\text { Concentration } \\
(\mathrm{mg} / \mathrm{kg})\end{array}$ & $\begin{array}{c}\text { Std. Dev. } \\
(\mathrm{mg} / \mathrm{kg})\end{array}$ \\
\hline $\mathrm{K}$ & 83723 & 415 \\
$\mathrm{Ca}$ & 16581 & 175 \\
$\mathrm{Ti}$ & 12120 & 134 \\
$\mathrm{Mn}$ & 2128 & 198 \\
$\mathrm{Fe}$ & 80203 & 547 \\
$\mathrm{Zn}$ & 702 & 30 \\
$\mathrm{As}$ & 99 & 13 \\
$\mathrm{Sr}$ & 173 & 6 \\
$\mathrm{Rb}$ & 907 & 19 \\
$\mathrm{Sb}$ & 20 & 10 \\
$\mathrm{Ba}$ & 559 & 10 \\
$\mathrm{U}$ & 72 & 8 \\
$\mathrm{Th}$ & 45 & 4 \\
\hline
\end{tabular}

Vermiculite (VTx-1)

\begin{tabular}{lcc}
\hline Element & $\begin{array}{c}\text { Concentration } \\
(\mathrm{mg} / \mathrm{kg})\end{array}$ & $\begin{array}{c}\text { Std. Dev. } \\
(\mathrm{mg} / \mathrm{kg})\end{array}$ \\
\hline $\mathrm{K}$ & 519 & 148 \\
$\mathrm{Ca}$ & 118451 & 326 \\
$\mathrm{CrLO}$ & 338 & 45 \\
$\mathrm{Mn}$ & 257 & 92 \\
$\mathrm{Fe}$ & 6186 & 145 \\
$\mathrm{Zn}$ & 63 & 14 \\
$\mathrm{Sr}$ & 44 & 3 \\
$\mathrm{Zr}$ & 6 & 1 \\
$\mathrm{Mo}$ & 4 & 2 \\
$\mathrm{Sb}$ & 15 & 9 \\
$\mathrm{Ba}$ & 7 & 2 \\
$\mathrm{Ag}$ & 44 & 17 \\
$\mathrm{U}$ & 14 & 3 \\
\hline
\end{tabular}


WSRC-TR-99-00229, Rev. 0

June 3, 1999

\section{Appendix B (Continued)}

Illite (I-API-35)

\begin{tabular}{lcc}
\hline Element & $\begin{array}{c}\text { Concentration } \\
(\mathrm{mg} / \mathrm{kg})\end{array}$ & $\begin{array}{c}\text { Std. Dev. } \\
(\mathrm{mg} / \mathrm{kg})\end{array}$ \\
\hline $\mathrm{CrHI}$ & 175 & 103 \\
$\mathrm{~K}$ & 42818 & 300 \\
$\mathrm{Ca}$ & 3518 & 95 \\
$\mathrm{Ti}$ & 4405 & 83 \\
$\mathrm{CrLO}$ & 79 & 52 \\
$\mathrm{Fe}$ & 39346 & 346 \\
$\mathrm{Co}$ & 162 & 116 \\
$\mathrm{Cu}$ & 51 & 18 \\
$\mathrm{Zn}$ & 166 & 17 \\
$\mathrm{As}$ & 63 & 12 \\
$\mathrm{Sr}$ & 154 & 5 \\
$\mathrm{Zr}$ & 186 & 4 \\
$\mathrm{Mo}$ & 4 & 3 \\
$\mathrm{Rb}$ & 197 & 8 \\
$\mathrm{Cd}$ & 36 & 25 \\
$\mathrm{Ba}$ & 248 & 6 \\
$\mathrm{Ag}$ & 25 & 17 \\
$\mathrm{U}$ & 25 & 5 \\
$\mathrm{Th}$ & 15 & 3 \\
\hline & &
\end{tabular}

\section{Kaolinite (KGa-2)}

\begin{tabular}{lcc}
\hline Element & $\begin{array}{c}\text { Concentration } \\
(\mathrm{mg} / \mathrm{kg})\end{array}$ & $\begin{array}{c}\text { Std. Dev. } \\
(\mathrm{mg} / \mathrm{kg})\end{array}$ \\
\hline $\mathrm{K}$ & 534 & 64 \\
$\mathrm{Ca}$ & 812 & 38 \\
$\mathrm{Ti}$ & 11527 & 115 \\
$\mathrm{Fe}$ & 6705 & 134 \\
$\mathrm{Zn}$ & 117 & 13 \\
$\mathrm{As}$ & 31 & 9 \\
$\mathrm{Sr}$ & 59 & 3 \\
$\mathrm{Zr}$ & 187 & 3 \\
$\mathrm{~Pb}$ & 7 & 6 \\
$\mathrm{Sb}$ & 6 & 6 \\
$\mathrm{Ba}$ & 16 & 2 \\
$\mathrm{U}$ & 41 & 3 \\
$\mathrm{Th}$ & 49 & 3 \\
\hline
\end{tabular}


Appendix B (Continued)

Illite (I-API-Green)

\begin{tabular}{lcc}
\hline Element & $\begin{array}{c}\text { Concentration } \\
(\mathrm{mg} / \mathrm{kg})\end{array}$ & $\begin{array}{c}\text { Std. Dev. } \\
(\mathrm{mg} / \mathrm{kg})\end{array}$ \\
\hline $\mathrm{K}$ & 54669 & 338 \\
$\mathrm{Ca}$ & 9713 & 132 \\
$\mathrm{Ti}$ & 4605 & 86 \\
$\mathrm{Mn}$ & 166 & 110 \\
$\mathrm{Fe}$ & 29978 & 307 \\
$\mathrm{Cu}$ & 124 & 20 \\
$\mathrm{Zn}$ & 140 & 16 \\
$\mathrm{As}$ & 59 & 11 \\
$\mathrm{Sr}$ & 88 & 4 \\
$\mathrm{Zr}$ & 152 & 3 \\
$\mathrm{Rb}$ & 218 & 9 \\
$\mathrm{Cd}$ & 36 & 20 \\
$\mathrm{Sn}$ & 25 & 13 \\
$\mathrm{Ba}$ & 149 & 5 \\
$\mathrm{U}$ & 30 & 5 \\
$\mathrm{Th}$ & 14 & 3 \\
\hline
\end{tabular}




\section{DISTRIBUTION}

Cynthia V. Anderson (1), 703-A, Rm E213N

Paul M. Bertsch (1), 737-A, Rm 199

Robert F. Blundy (1), 730-2B, Rm 2003

B. Tom Butcher (1) 737-A, Rm 216

John B. Gladden (1), 773-42A, Rm 242

Howard M. Hickey (1) 730-2B, Rm 2147

Tom G. Hinton (5) 737-G, Rm 1

Dan I. Kaplan (1), 773-43A, Rm 215

Anna C. Knox (1), 737-A, Rm 155

Christine A. Langton (1), 773-43A, Rm 2219

Cathy M. Lewis (3), 730-2B, Rm 3164

Bart C. Marcy (1), 773-42A, Rm 212

Deb Moore-Shedrow (1) 773-A, Rm A229

Charles Murphy (1), 773-42A, Rm 222

Barry Myers (1) 707C, Rm 328

Jerry J. Nelsen (1), 703-A, Rm E211S

Lawrence N. Oji (1), 773-43A, Rm 229

Phillip M. Prater (1), 703-A, Rm E219N

Dennis P. Ryan (1), 703-A, Rm B118

Bruce G. Schappell (1) 730-2B, Rm 329

John C. Seaman (1), 737-A, Rm 155

Steven M. Serkiz (1), 703-A, Rm B121

Carl L. Strojan (1), 737-A, Rm 311

Michael H. Smith (1), 737-A, Rm 307

W. Ed Stevens (1), 773-A, Rm A261

Anthony Towns (1), 703-A, Rm B204

STI (4), 703-43A 